\title{
Biodiversity patterns, environmental drivers and indicator species on a High-temperature Hydrothermal edifice, mid-Atlantic ridge
}

\author{
Sarrazin Jozée ${ }^{1, *}$, Legendre Pierre ${ }^{2}$, De Busserolles Fanny ${ }^{1,3}$, Fabri Marie-Claire ${ }^{1}$, Guilini Katja ${ }^{4}$, \\ Ivanenko Viatcheslav ${ }^{5}$, Morineaux Marie ${ }^{1}$, Vanreusel Ann ${ }^{4}$, Sarradin Pierre-Marie ${ }^{1}$
}

${ }^{1}$ Ifremer, Centre de Bretagne, REM/EEP, Laboratoire Environnement Profond, Institut Carnot EDROME, F-29280 Plouzané, France

${ }^{2}$ Département de sciences biologiques, Université de Montréal, C.P. 6128, succursale centre-ville, Montréal, Québec H3C 3J7, Canada

${ }^{3}$ Red Sea Research Centre, King Abdullah University of Science and Technology, Thuwal 23955-6900, Saudi Arabia

${ }^{4}$ Marine Biology Section, Department of Biology, Ghent University, Krijgslaan 281/S8, 9000 Ghent, Belgium

${ }^{5}$ Department of Invertebrate Zoology, Biological Faculty, Lomonosov Moscow State University, Leninskie Gory, 1-12 Moscow 119992, Russia

* Corresponding author : Jozée Sarrazin, email address : jozee.sarrazin@ifremer.fr

\begin{abstract}
:
Knowledge on quantitative faunal distribution patterns of hydrothermal communities in slow-spreading vent fields is particularly scarce, despite the importance of these ridges in the global mid-ocean system. This study assessed the composition, abundance and diversity of 12 benthic faunal assemblages from various locations on the Eiffel Tower edifice (Lucky Strike vent field, Mid-Atlantic Ridge) and investigated the role of key environmental conditions (temperature, total dissolved iron (TdFe), sulfide (TdS), copper $(\mathrm{TdCu})$ and $\mathrm{pH}$ ) on the distribution of macro- and meiofaunal species at small spatial scales $(<1 \mathrm{~m})$. There were differences in macro- and meiofaunal community structure between the different sampling locations, separating the hydrothermal community of the Eiffel Tower edifice into three types of microhabitats: (1) cold microhabitats characterized by low temperatures $\left(<6{ }^{\circ} \mathrm{C}\right)$, high $\mathrm{TdCu}$ (up to $2.4 \pm 1.37 \mu \mathrm{mol} \mathrm{I}-1$ ), high $\mathrm{pH}$ (up to $7.34 \pm 0.13$ ) but low TdS concentrations $(<6.98 \pm 5.01$ $\mu \mathrm{mol}$ I-1); (2) warm microhabitats characterized by warmer temperatures $\left(>6{ }^{\circ} \mathrm{C}\right)$, low $\mathrm{pH}(<6.5)$ and high TdS/TdFe concentrations $(>12.8 \mu \mathrm{mol} \mathrm{I}-1 />1.1 \mu \mathrm{mol} \mathrm{I}-1$ respectively); and (3) a third microhabitat characterized by intermediate abiotic conditions. Environmental conditions showed more variation in the warm microhabitats than in the cold microhabitats. In terms of fauna, the warm microhabitats had lower macro- and meiofaunal densities, and lower richness and Shannon diversity than the cold microhabitats. Six macrofaunal species (Branchipolynoe seepensis, Amathys lutzi, Bathymodiolus azoricus, Lepetodrilus fucensis, Protolira valvatoides and Chorocaris chacei) and three meiofaunal taxa (Paracanthonchus, Cephalochaetosoma and Microlaimus) were identified as being significant indicator species/taxa of particular microhabitats. Our results also highlight very specific niche separation for copepod juveniles among the different hydrothermal microhabitats. Some sampling units showed
\end{abstract}


unique faunal composition and increased beta diversity on the Eiffel Tower edifice. Contrary to what was expected, the highest beta diversity was not associated with a particular microhabitat type, but rather with location on the central part of the edifice where other structuring factors may predominate.

\section{Introduction}

Hydrothermal vents are generally located on mid-oceanic ridges and back-arc basins. These dynamic and ephemeral ecosystems have high temperature emissions (up to $400{ }^{\circ} \mathrm{C}$ ), are rich in reduced chemicals and contain potentially toxic heavy metals and radionuclides (Johnson and Tunnicliffe, 1985, Johnson et al., 1988, Sarradin et al., 1999, Luther et al., 2001 and Charmasson et al., 2009). These emissions can either produce wide areas of diffuse flow on the ocean floor or form large sulfide edifices that can reach several meters in height. A unique set of fauna can colonize these habitats in areas where reduced hydrothermal fluids mix with oxygenated seawater (Johnson et al., 1988 and Luther et al., 2001). In general, hydrothermal communities exhibit high biomass, strong endemism and low species richness compared to other deep-sea ecosystems (Tunnicliffe, 1991 and Van Dover et al., 2002). Their structure and composition are influenced by a combination of factors occurring at different spatial and temporal scales (Bachraty et al., 2009).

At the ocean scale, these factors include the mechanisms that interconnect or isolate different hydrothermal fields (Hessler and Lonsdale, 1991 and Desbruyeres et al., 2001), the presence of various spreading rates, the occurrence of hydrographic barriers and the unpredictable nature of geological processes (Tunnicliffe, 1988 and Tunnicliffe, 1991; Desbruyères et al., 1994; Tunnicliffe et al., 1997, Sarrazin et al., 1997, Shank et al., 1998, Tsurumi and 
Tunnicliffe, 2001; Van Dover et al., 2002). At smaller spatial scales (e.g., edifice scale), high temporal variability in physical and chemical conditions influences the composition, distribution and dynamics of vent assemblages, depending on species tolerance to the toxicity of the fluids and also, on their nutritional requirements (Hessler et al., 1988; Fisher et al., 1988; Johnson et al., 1988; Tunnicliffe, 1991; Sarrazin et al., 1997, 1999, 2002, 2006a; Comtet and Desbruyères, 1998; Shank et al., 1998; Sarrazin and Juniper, 1999; , Lee, 2003; Mullineaux et al., 2003; Bates et al., 2005; Govenar et al., 2005; Kelly et al., 2007; Matabos et al., 2008; Nees et al., 2008, 2009; Cuvelier et al., 2009; Gebruk et al., 2010; Fabri et al, 2011; Tokeshi, 2011; Nye et al. 2013).

The mixing zone between hydrothermal fluids and bottom seawater is subject to narrow spatial and temporal gradients of abiotic conditions, which may critically affect the concentrations of the substrates used as energy and carbon sources for chemosynthetic processes (Le Bris et al., 2003). Several authors have shown that local abiotic conditions affect the abundance of microorganisms (Sievert et al., 1999) and even the composition of nutritive resources available (Levesque et al., 2005), causing variations in isotopic carbon signatures in vent species within a single edifice (Colaço et al., 2002; Limen et al., 2007; De Busserolles et al., 2009). Moreover, biotic factors such as competition, predation and larval recruitment may play a significant role in structuring vent communities by limiting their distribution to a specific niche (Comtet and Desbruyères, 1998; Micheli et al., 2002; Levesque et al., 2003; Mullineaux et al., 2003; Bates et al., 2005; Dreyer et al., 2005; Lenihan et al., 2008; Lutz et al., 2008; Nees et al., 2008; Podowski et al. 2009). Hence, each single hydrothermal site has a more or less distinct faunal composition, depending on its geographical position, with small-scale variations (decimeter- to meter scales) in faunal density, diversity and biomass.

Between $23^{\circ}$ and $37^{\circ} \mathrm{N}$, mid-Atlantic ridge (MAR) faunal assemblages are dominated by mussel beds and shrimp aggregations (Desbruyères et al., 2001). On the Lucky Strike vent field, they patchily colonize the active Eiffel Tower edifice $(11 \mathrm{~m})$ with a spatial distribution that is strongly linked to their distance from local fluid emissions and local environmental conditions (Cuvelier et al., 2009, 2011a, b). Although four different types of assemblages have been recognized on video imagery, there are two slightly overlapping niches, with 
Bathymodiolus azoricus assemblages preferentially colonizing low temperature habitats (4.4 to $6.1^{\circ} \mathrm{C}$ ) and Mirocaris fortunata shrimp assemblages located in slightly warmer and more variable habitats $\left(5.2\right.$ to $9.5^{\circ} \mathrm{C}$; Cuvelier et al., 2009). Notwithstanding, the exact composition of the different meio- and macrofaunal assemblages and the detailed physical and chemical characterization of their habitats have never been systematically surveyed at the scale of Eiffel Tower, and only on a few occasions on a single MAR edifice (Copley et al., 1997; Gebruk et al., 2000; Van Dover, 2002, 2003; Cuvelier et al., 2009, 2011b; Fabri et al., 2011).

The objective of this study was to describe the composition, abundance and diversity of 12 benthic faunal assemblages from various locations on the Eiffel Tower edifice (MAR) with respect to the characteristics of their habitats. We addressed the following questions: Are there differences in macro- and meiofaunal community structure between sampling locations on a single edifice? Are there significant spatial patterns in macro- and meiofaunal species distribution at the edifice-scale and/or with respect to environmental conditions? And finally, are there identifiable indicator species linked to specific environmental conditions?

\section{Materials and Methods}

\subsection{Study site}

The MoMARETO cruise took place in 2006 on the French research vessel Pourquoi pas? equipped with the remotely operated vehicle (ROV) Victor6000 (Sarrazin et al., 2006b). Faunal and chemical data were collected on the Eiffel Tower sulfide edifice, located at $\sim 1700 \mathrm{~m}$ depth in the Lucky Strike vent field on the MAR. To obtain a representative overview of the faunal community, 12 locations (C1 to C12) were chosen at different depths on either side of the edifice (Fig. 1). Choice of sampling locations was strongly influenced by ROV accessibility, and the number of locations depended on the ROV time available for this experiment. Maximum distance between the sampling locations was $21 \mathrm{~m}$ (between $\mathrm{C} 9$ and C10), while minimum distance was $50 \mathrm{~cm}$ (between $\mathrm{C} 2$ and C3).

\subsection{Environmental characterization}

Temperature and key chemical conditions $(\mathrm{pH}$, total dissolved iron, sulfide and copper concentrations) were assessed for each of the 12 sampling units (C1 to C12) with in 
situ measurements and water sampling (Table 1; see detailed sampling protocol in De Busserolles et al., 2009 and Sarradin et al., 2009). Total dissolved iron (TdFe) and sulfide (TdS) concentrations $\left(\mathrm{H}_{2} \mathrm{~S}, \mathrm{HS}^{-}, \mathrm{S}^{--}\right)$were measured in situ using the chemical analyzer CHEMINI (Vuillemin et al., 2009). The selected environmental variables are good proxies for assessing the hydrothermal input within the studied microhabitats: iron and copper are important metal species in hydrothermal fluids, sulfide is one of the main energy sources for chemosynthesis and finally, $\mathrm{pH}$ and temperature can be used as dilution indicators. All of these variables, depending on their speciation and concentrations, can be either essential or harmful to living organisms (Bebianno et al., 2005; Cosson et al., 2008; Company et al., 2004, 2010; Martins et al., 2011a, b).

Temperature was measured with an autonomous temperature probe (NKE) attached to the sampling inlet. Water samples were collected with the PEPITO sampling device (Sarradin et al., 2009). pH was measured on board at $25^{\circ} \mathrm{C}$ using a combined $\mathrm{pH}$ electrode (Ingold ${ }^{\circledR}$ ) for sulfide-rich medium after calibration with NBS buffers ( $\mathrm{pH} 4$ and 7), and total dissolved copper ( $\mathrm{TdCu}$ ) was measured by stripping chronopotentiometry (SCP) with a gold electrode (Riso et al., 1997). A reference temperature was measured outside the area influenced by hydrothermal fluids using the ROV probe. All abiotic sampling and analytical procedures are described in Sarradin et al. (2009).

\subsection{Faunal sampling and identification}

After characterizing the environment, fauna was sampled using Victor's suction sampler and arm grab following the protocol described in Cuvelier et al. (2012). Once brought on board, faunal samples from each location were washed over stacked sieves (1 $\mathrm{mm}, 250 \mu \mathrm{m}$ and $63 \mu \mathrm{m}$ mesh sizes) and fixed in 4\% buffered formalin. After two days, all fractions were transferred to $70 \%$ ethanol for further analyses. All macrofauna ( $>250 \mu \mathrm{m}$ ) organisms were identified to the lowest taxonomic level possible following Desbruyères et al. (2006). Some polychaete and shrimp taxa were undetermined, usually because the specimens were too damaged to precisely identify the taxon. Mussel lengths were measured for each sampling unit. 
Meiofauna $(250 \mu \mathrm{m}>\mathrm{x}>63 \mu \mathrm{m})$ were extracted from the sediment using a triple density centrifugation at $3000 \mathrm{rpm}$ for $12 \mathrm{~min}$ with the colloidal silica polymer LUDOX TM 40 and stained with Rose Bengal. All meiofaunal organisms were sorted, counted and identified to the higher taxonomic level possible (genus levels for nematodes, following Higgins and Thiel, 1988) using a stereomicroscope (100x magnification). Some samples required subsampling prior to meiofaunal identification due to over-abundance of individuals (samples C1, C3, C4, C5, C9, C11 and C12). Consequently, 200 nematodes per sample were randomly extracted with a needle and gradually transferred to glycerine (Seinhorst, 1959) prior to being mounted on permanent glass slides and identified to the genus level under a compound microscope (1000x magnification) using the pictorial key from Warwick et al., (1998). This method gives an accurate representation of the total number of genera present in the sample but may lead to the underestimation of those that are rare. Copepods were picked from the fractions retained on both the $250 \mu \mathrm{m}$ and $63 \mu \mathrm{m}$ sieves. They were identified to the lowest taxonomic level possible (usually family level) under a light microscope after being cleared in lactic acid or glycerol, stained with a solution of chlorazol black $E$ and, examined with bright-field or with differential interference optics. All copepod dissections and identifications were made in lactic acid or glycerol (Ivanenko and Defaye, 2004). Since only the meiofauna larger than $63 \mu \mathrm{m}$ was examined, we assume that the abundance and diversity found within this study are underestimates, except for copepods for which a large number of nauplii and juveniles were found.

\subsection{Surface analysis}

For each sampled unit, the surface area was estimated using the IP Lab Spectrum image analysis software on numerical images taken before and after sampling (according to Sarrazin et al., 1997). Each area was analyzed three times by different observers to reduce error from on-screen tracing (see details in Cuvelier et al., 2012). Even though it is the only way to sample surface for hard substratum samples, this method does not take into account the relief or the thickness of the faunal coverage, inducing a bias in density estimates. Even though densities (individuals per $\mathrm{m}^{2}$ ) were calculated for each area, the data from location C9 are likely inaccurate because some sampling problems occurred (clogging of the suction sampler). We nevertheless chose to include this site in the analyses, because it had a very distinct set of fauna (see results below). 


\subsection{Data analysis}

Prior to statistical analyses, we considered and compared several transformations for the species data; ultimately, we Hellinger-transformed the macrofaunal and meiofaunal densities prior to the analyses (Legendre and Gallagher, 2001). This transformation does not give more importance to the rare taxa in the assessment of dissimilarity (Gauthier et al., 2010). The principal component analyses (PCAs) were computed separately for the macrofauna and meiofauna. We also looked for the best combination of explanatory environmental variables, which included the mean, maximum and minimum values as well as the difference between the maximum and the minimum (delta) for temperature $\left(T^{\circ} \mathrm{C}\right.$ ), total dissolved iron (TdFe), sulfide (TdS), copper ( $T d C u)$ and $\mathrm{pH}$. Given that most of these variables were inter-correlated, we selected four variables that were less collinear than other variable combinations (based on variance inflation factor coefficients): $\mathrm{T}^{\circ} \mathrm{C}$.mean, S.mean, Cu.mean, pH.mean. Fe.mean was not included because there was no relationship between species variations and that variable. The four selected variables were included in a principal component analysis (PCA) whose axes represent the main components of environmental variation (Fig. 2). The four variables were standardized prior to the PCA.

Canonical redundancy analyses (RDAs) were used to evaluate the influence of environmental conditions on macrofaunal and meiofaunal distributions as well as on the presence/absence of copepod nauplii and copepodid stages. Species richness, faunal density and Shannon diversity were computed separately for the macrofauna and meiofauna for the 12 sampling units (C1-C12) on the Eiffel Tower edifice. Diversity was assessed using the Shannon diversity index $H, N=\exp (H)$, and plotted following the recommendations of Ellison (2010). Local indicators of beta diversity (LCBD indices, computed using the $\mathrm{R}$ function beta.div available in Legendre and De Cáceres, 2013) were also computed for both faunal compartments. LCBD indices represent the degree of uniqueness of the fauna in individual sampling units in terms of community composition. Faunal densities, richness, diversities and LCBD indices were plotted on maps of the hydrothermal edifice according to their $X$ and Y coordinates. 
Indicator species analysis (Dufrêne and Legendre, 1997; De Cáceres and Legendre, 2009; Legendre and Legendre, 2012; Section 8.9.3) was conducted to identify the macrofaunal and meiofaunal taxa that were significantly associated with particular environmental conditions. All multivariate analyses were performed in the $R$ environment ( $R$ Development Core Team 2012), using the vegan (Oksanen et al., 2012), and packfor (Dray, 2012), mvpart (De'ath, 2012) and indicspecies (De Cáceres and Jansen 2011) packages.

\section{Results}

\subsection{Environmental conditions}

Mean temperatures varied from $4.8^{\circ} \mathrm{C}$ to $8.8^{\circ} \mathrm{C}$, a relatively narrow temperature range for hydrothermal ecosystems (Table 1). The bottom seawater temperature at $1700 \mathrm{~m}$ depth measured in this area was $\sim 4.4^{\circ} \mathrm{C}$. Our results showed that the sampling units with the warmest temperature values $(\mathrm{C} 2, \mathrm{C} 8$ and $\mathrm{C} 10)$ also had the highest concentrations of TdS and TdFe and lower pH (Table 1). On the other hand, the coolest locations C1, C9 and C12 exhibited some of the lowest TdS and TdFe concentrations and the highest pH. However, although TdFe and TdS concentrations were positively correlated with temperature, $\mathrm{TdCu}$ and $\mathrm{pH}$ showed negative correlations (De Busserolles et al., 2009). The highest TdCu concentrations were found at the low temperature location C9, followed by C4 (Table 1).

Overall, mean TdS and TdFe concentrations were, respectively, 10 and 3 times higher in the warm microhabitats than in the cold ones, with much larger variations as shown by their standard deviations (Table 1). Conversely, mean TdCu was two times higher in the cold microhabitats (Table 1). Finally, the warm microhabitats exhibited a more acidic pH (Table 1).

PCA analyses (Fig. 2) confirmed that the microhabitats on Eiffel Tower can be divided into three groups (two of which are consistent with De Busserolles et al., 2009). These microhabitats are characterized by different environmental conditions separating the cold sites (sampling units $\mathrm{C} 1, \mathrm{C} 3, \mathrm{C} 4, \mathrm{C} 5, \mathrm{C} 7, \mathrm{C} 9, \mathrm{C} 11, \mathrm{C} 12$ ) from the warm sites (sampling units $\mathrm{C2}, \mathrm{C} 8, \mathrm{C10})$, with $\mathrm{C} 6$ being intermediate.

\subsection{Sampling surfaces}


The surface area estimated for each sampling units is shown in Table 1. The overall mean sampling surface was $\sim 0.05 \pm 0.02 \mathrm{~m}^{2}$. Area estimations varied slightly depending on the observer and the sampling locations, but there were no significant differences (see Cuvelier et al., 2012 for the method used and result of the test). From the mean values, C7 was the microhabitat with the smallest sampling area $\left(0.01 \mathrm{~m}^{2}\right)$, whereas $\mathrm{C} 3$ had the largest sampling area $\left(0.082 \mathrm{~m}^{2}\right)$, covering a surface more than eight times that of C7 (Table 1). This may have a significant impact on the results, especially for diversity data.

\subsection{Macro- and meiofaunal community description}

A total of 70 taxonomic groups (macrofauna + meiofauna) were identified in the Eiffel Tower samples (Tables 2 to 5), among a total of 163,552 individuals. The meiofaunal fraction $(250 \mu \mathrm{m}>\mathrm{x}>63 \mu \mathrm{m})$ dominated $(84.9 \pm 14.2 \%)$ faunal abundance in all sampling units, with two genera of nematodes (Cephalochaetosoma and Halomonhystera) dominating 11 of the 12 sampling units $(59.9 \pm 21.5 \%)$. Only C 6 was dominated by dirivultid copepods of the order Siphonostomatoida, representing $\sim 53 \%$ of the total faunal abundance. The macrofaunal fraction $(>250 \mu \mathrm{m})$ only represented a small part of the total abundance, varying from $2 \%$ $(\mathrm{C} 3, \mathrm{C} 5)$ to $38 \%(\mathrm{C} 7, \mathrm{C} 8)$.

Analysis of the distribution of macro- and meiofaunal taxa among the sampling units revealed that five taxa were observed in all 12 sampling units (Branchipolynoe seepensis, Amathys lutzi, Bathymodiolus azoricus, Halomonhystera nematodes and Dirivultidae copepods) and eight taxa (the above-listed taxa and Mirocaris fortunata, Cephalochaetosoma and Microlaimus) were present in 11 sampling units. In contrast, 16 faunal taxa were only present in one sampling unit, and 11 taxa were only present in two, resulting in 27 taxa with "rare" occurrence in our dataset (data not shown).

The highest macrofaunal taxonomic richness was observed in C3 and C11 with 23 taxa. The lowest macrofaunal richness was found in $\mathrm{C} 10$ and $\mathrm{C7}$ with, respectively, 7 and 8 taxa (Table 3). Similarly, for the meiofauna, the highest richness was observed in C3 and C11 with, respectively, 18 and 19 taxa. The lowest meiofaunal richness was found in C2 and C6 with 7 meiofaunal taxa (Table 5). 


\subsection{Macrofaunal community structure}

We observed 41 macrofaunal taxa (among which 20 were identified to the species level) in the 12 sampling units among a total of 6296 individuals. Overall, 20 polychaete taxa were found, accounting for 4.3 to $75.1 \%$ of the macrofaunal abundance $(34.9 \pm 23 \%$, Table 2). Bathymodiolus azoricus mytilid mussels and Alvinocarididae shrimps - with two identified species from 2 genera - were the second and third most dominant macrofaunal taxa representing, respectively, 5 to $41.2 \%(26.2 \pm 11.8 \%)$ and 0 to $82.4 \%(24.3 \pm 30.7 \%)$ of the total macrofaunal abundance. Gastropods accounted for 0 to $30 \%$ of macrofaunal abundance, with a mean of $9.0 \pm 10.1 \%$ (Table 2 ).

More specifically, sampling unit $\mathrm{C} 1$ was dominated by $B$. azoricus mussels and to a lesser extent by Branchipolynoe seepensis and Amathys lutzi polychaetes (Table 2). Protolira valvatoides gastropods were also present in $\mathrm{C} 1$, representing $10 \%$ of the relative abundance. C2 was dominated by Mirocaris fortunata shrimp and B. azoricus. A. lutzi polychaetes were also relatively abundant. C3 was largely dominated by $A$. luzti (>68\%) and to a lesser extent by $B$. azoricus mussels. C4 was almost evenly dominated by three taxa: Ophyotrocha $s p$. and A. lutzi polychaetes as well as by $B$. azoricus mussels. C5 was largely dominated by $B$. azoricus (>41\%) as well as by A. lutzi. C6 was dominated by $M$. fortunata shrimp and to a lesser extent by amphipods and B. azoricus. C7 was largely dominated by $M$. fortunata (>77\%), with B. azoricus and Shinkailepas briandi gastropods as main accompanying species. M. fortunata was also very abundant in C8 followed by the second species of shrimp Chorocaris chacei. B. azoricus dominated C9, followed by P. valvatoides and Actiniaria. The latter taxon was present only in two of the 12 sampling units (C3 and C9). B. azoricus also dominated $\mathrm{C} 10$ with a relative abundance similar to that found in C9. M. fortunata was the second most dominant taxon followed by B. seepensis. C11 was almost equally dominated by $B$. azoricus and $P$. valvatoides, with $A$. lutzi as the third dominant species. A. lutzi polychaetes dominated C12 (>47\%) followed by B. azoricus and to a lesser extent $B$. seepensis (Table 2).

In terms of density, the highest macrofaunal densities were observed in sampling units C12 $\left(24,375 \mathrm{ind} / \mathrm{m}^{2}\right), C 9\left(20,077 \mathrm{ind} / \mathrm{m}^{2}\right)$ and C5 $\left(19,061 \mathrm{ind} / \mathrm{m}^{2}\right)$, whereas the lowest densities were found in C2, C10 and C8 (with 3757, 4246 and 4250 ind/m², respectively; 
Table 3). The macrofaunal taxonomic richness was highest in C3 and C11 (23 taxa) followed by C1 (22 taxa), while the lowest was found in C7 and C10 with only 7 to 8 taxa present (Table 3). Polychaetes dominated the abundance of 6 of the 12 sampling units (C1, C3, C4, $\mathrm{C} 5, \mathrm{C} 11, \mathrm{C} 12$ ), with a higher richness in $\mathrm{C} 3$ and $\mathrm{C} 1$ (Table 3). The number of gastropod taxa peaked in $\mathrm{C} 1$ and was also high ( 5 taxa) in $\mathrm{C} 5$ and $\mathrm{C} 11$. Mytilids dominated the macrofaunal abundance in C5 and C1, C9, while alvinocaridids dominated the abundance in three sampling units (C2, C7, C8, Table 3). Gastropods were absent from C10 and similarly shrimp were completely absent from C5 (Table 3). Mussel lengths varied significantly among the sampling units, the larger mussels being found in C8, C2, C6 and C10 and the smaller ones in C11, C5 and C12 (Table 1).

\subsection{Meiofaunal community structure}

We observed 29 meiofaunal taxa in the 12 sampling units among a total of 157,256 individuals. The presence/absence of juveniles and larval stages was noted. The meiofaunal compartment, ranging from 63 to $250 \mu \mathrm{m}$, accounted for $62 \%(C 7, C 8)$ to $98 \%(C 3, C 5)$ of the total faunal abundance in the Eiffel Tower assemblages when compared to the macrofauna. In terms of relative abundance, the nematodes largely dominated the meiofauna in all sampling units (>87\%), with the exception of C6 that was dominated by dirivultid copepods (Table 5). The other taxonomic groups only represented a small proportion $(<4 \%)$ of the meiofauna. Total meiofaunal densities varied from 6857 (C8) to 747,041 (C3) individuals per $\mathrm{m}^{2}$ (Table 5). C12, C3, C5 exhibited the highest densities with $>500000 \mathrm{ind} / \mathrm{m}^{2}$. C9, C2, C4, C1 and $\mathrm{C} 11$ had intermediate densities, while C8, C10, C6 and C7 showed lower faunal densities $\left(<22,800 \mathrm{ind} / \mathrm{m}^{2}\right.$, Table 5$)$.

Overall, there were 13 nematode genera belonging to 12 families, all of them already known to science (Table 4). In each sampling unit, 2 to 10 nematode genera were found (Table 5). Cephalochaetosoma and Halomonhystera dominated all but one sampling unit (C6) and, without this exception, accounted for $71 \pm 23.2 \%$ of the relative meiofaunal abundance. More specifically, C1 was dominated by Cephalochaetosoma nematodes (Table 4) and represented by six nematode and seven copepod families (Table 5). C2 was largely dominated by Halomonhystera nematodes (Table 4) and had the smallest meiofaunal taxonomic richness, together with C6 (7 taxa in each) and the smallest number of nematode 
genera (Table 5). C3 was dominated by Cephalochaetosoma nematodes and several other nematode genera. It also had a relatively high abundance of Smacigastes micheli tegastid copepods (Table 4) and one of the highest taxonomic richness with 18 taxa present (Table 5). C3 also harbored the largest abundance of acarines. Similar to C3, C4 was dominated by Cephalochaetosoma. It was characterized by an intermediate richness with 14 taxa, including six nematode and six copepod taxa (Table 5). C5 had nine nematode genera among which three (Cephalochaetosoma, Leptolaimus and Microlaimus) were dominant (Table 5). Four other nematode genera as well as tegastid copepods were also relatively abundant (Table 4). C6 was largely dominated by dirivultid copepods, with Halomonhystera nematodes representing the second most dominant taxon. It had one of the lowest richness values with only 7 taxa present (Table 5). Ostracods were also relatively abundant in this sampling unit ( 4\%, Table 4). C7 was dominated by Halomonhystera nematodes, and ostracods represented $>2 \%$ of the abundance (Table 4). Similar to C7, C8 was also largely dominated by Halomonhystera nematodes and had one of the lowest richness values with a total of 6 nematode and 2 copepod taxa (Table 5). No other taxa were represented. C9 was almost exclusively dominated by nematodes $(99.8 \%)$ which mostly belonged to three genera: Cephalochaetosoma, Microlaimus and Halomonhystera (Table 4). It had the highest number of nematode genera (10) together with the lowest number of copepod family/species (1 family, Table 5). C10 was also largely dominated by nematodes (99.5\%), mainly Halomonhystera and Cephalochaetosoma (Table 4). C11 had the highest taxonomic richness, with 19 taxa distributed among the copepods ( 7 taxa), nematodes (9 taxa) and three other taxa present in the meiofaunal samples (Table 5). Similar to C9, it was dominated by Cephalochaetosoma. Among the copepods, the dirivultids dominated. Finally, C12 was largely dominated by Cephalochaetosoma with Chromatodorita as the second most dominant nematode taxon (Table 4). Similar to C4, C12 had an intermediate richness, with 14 taxa distributed between nematodes ( 6 taxa), copepods (6 taxa) and 2 other taxa (Table $5)$.

We observed 11 families of copepods in the $250 \mu \mathrm{m}$ samples (Table 4). The $63 \mu \mathrm{m}$ fraction contained 10 families for which diverse copepodids and naupliar stages were tentatively identified (Table 6). A total of 7 families were common to both fractions. The calanoid Spinocalanoidae (represented by a single specimen of a new genus) and 
Aegisthidae were not present at the $63 \mu \mathrm{m}$ fraction as juveniles (Tables 4, 6). Inversely, the other Calanoida, Ancorabolidae and Canthocamptidae were not found as adults in the samples (Table 4), but the two latter were present as copepodids in the $63 \mu \mathrm{m}$ fraction (Table 4). Dirivultidae and Tegastidae alternately dominated the copepod families representing, respectively, an average of $58.6 \pm 37.9 \%$ and $27.9 \pm 35.9 \%$ of the relative copepod abundance. Among the copepods, dirivultids dominated eight sampling, units while tegastids dominated the remaining four (C3, C4, C5, C12). Subadult copepodids and nauplii of different copepod families were present in all 12 sampling units (Table 6). Some sampling units were particularly rich in earlier stages (C11 and C12), while others like C7, C8 and C9 only had a few subadult/nauplii. Calanoida copepodids (except Spinocalanidae) were only present in two sampling units $(\mathrm{C} 10, \mathrm{C} 12$; Table 6). Interestingly, what seem to be Pseudotachidiidae nauplii were only present in C2 and C10, but their copepodids including adults were found in 9 of the 12 sampling units. Conversely, Dirivultidae and Miraciidae nauplii were present in most (11) sampling units, while the other unidentified nauplii were present in all units (Table 6).

\subsection{Environmental characterization}

The first two components of the PCA on environmental data accounted for $39 \%$ of the variance in abiotic conditions of the 12 sampling units (Fig. 2). The PCA indicates that the sampling units showed a gradient in environmental conditions ranging from those characterized by high $\mathrm{TdCu}$ concentrations, high $\mathrm{pH} /$ low temperature and low $\mathrm{TdS}$ concentrations (cold microhabitats) to those characterized by low TdCu concentrations, low $\mathrm{pH} /$ high temperature, and high TdS concentrations (warm microhabitats, Fig. 2). The cold microhabitats included, in an increasing gradient of environmental conditions $\mathrm{C} 9<\mathrm{C} 12<\mathrm{C} 1<\mathrm{C} 5-\mathrm{C} 11-\mathrm{C} 3-\mathrm{C} 4-\mathrm{C} 7$, whereas the warm microhabitats included $\mathrm{C} 2<\mathrm{C} 8<\mathrm{C} 10$. C6 can be considered as an intermediate microhabitat (Fig. 2).

\subsection{Faunal distribution and environmental conditions}

Macrofauna- The first two components of the RDA on the macrofaunal density data accounted for $\sim 39 \%$ of the variance in macrofaunal distribution of the 12 sampling units (Fig. 3). The RDA showed that the Eiffel Tower macrofaunal assemblages could be separated into two types: (1) the warm microhabitats $(C 2, C 4, C 8, C 7)$ colonized preferentially by 
alvinocaridid shrimp and to a lesser extent by Shinkailepas briandi gastropods; and (2) the cold microhabitats $(\mathrm{C} 1, \mathrm{C} 3, \mathrm{C} 5, \mathrm{C}, \mathrm{C} 11, \mathrm{C} 12)$ preferentially colonized by five species (Bathymodiolus azoricus, Amathys lutzi, Branchipolynoe seepensis, Protolira valvatoides, Lepetodrilus atlanticus). Other taxa, such as Ophryotroca, Pycnogonida, Lirapex costellata and Lurifax vitreus were, to a lesser extent, also linked with the cold microhabitats (Fig. 3). Sampling units $\mathrm{C4}, \mathrm{C} 6$ and $\mathrm{C} 7$ were characterized by intermediate macrofaunal densities.

Meiofauna- The first component of the RDA on the meiofaunal density data accounted for $\sim 31.6 \%$ of the variance in meiofaunal distribution of the 12 sampling units (Fig. 4). The RDA showed that the Eiffel Tower meiofaunal assemblages could, as it is the case for environmental conditions, be separated into three types: (1) the warm microhabitats (C2, C8) colonized preferentially by Halomonhystera; (2) the intermediate microhabitat (C6); and (3) the cold microhabitats $(\mathrm{C} 9, \mathrm{C} 12, \mathrm{C} 1)$ preferentially colonized by three nematode genera (Cephalochaetosoma, Paracanthonchus and Microlaimus, Fig. 4). Other taxa, such as Ostracoda, Tanaidacea and Cyclopinidae were, to a lesser extent, also linked with the cold microhabitats (C11, C5, C4, C3, C7, Fig. 4) which are characterized by intermediate meiofaunal densities.

Nauplii/copepodids - The first two components of the RDA on the copepod nauplii and copepodid presence/absence data accounted for $\sim 45.9 \%$ of the variance in distribution of the 12 sampling units (Fig. 5). Interestingly, the RDA showed that the Eiffel Tower copepod "juvenile" assemblage distribution was quite complex. It can be separated into four types: (1) the microhabitat (C8) with the highest TdS concentration was characterized by the presence of tisbid copepodids (subadults and adults); (2) the microhabitats (C2, C10, C6, C7, C4) characterized by high temperature and high TdS concentrations were preferentially colonized by dirivultid copepodids and to a lesser extent by Pseudotachidiidae and dirivultid nauplii as well as by Canthocamptidae and Ectinosomatidae copepodids; (3) the microhabitats characterized by intermediate conditions $(\mathrm{C} 1, \mathrm{C} 3, \mathrm{C} 11, \mathrm{C} 5)$ were preferentially colonized by Miraciidae and Canthocamptidae nauplii as well as Pseudotachidiidae and Miraciidae copepodids; and (4) the intermediate to high pH microhabitats (C12, C9) were preferentially colonized by Ancorabolidae and Cyclopinidae copepodids as well as by nauplii 
of Tegastidae (Fig. 5). These results suggest very specific niche separations for copepod juveniles in hydrothermal microhabitats.

\subsection{Presence of indicator species}

Indicator species analyses were carried out to identify which species among the 70 taxa identified on the Eiffel Tower edifice would be good indicators for the two major types (cold/warm) of microhabitats encountered. Six significant macrofaunal indicator species were identified; most of them (5) belonging to the cold microhabitat group. This group is represented by Branchipolynoe seepensis ( $p=0.032)$, Amathys luzti $(p=0.008)$, Bathymodiolus azoricus $(p=0.004)$, Lepetodrilus fucensis $(p=0.01)$ and Protolira valvatoides $(p=0.03)$. The warm microhabitat group is only represented by the shrimp Chorocaris chacei $(p=0.004)$.

For the meiofauna, three nematode genera were identified as significant indicators. Paracanthonchus $(p=0.020)$, Cephalochaetosoma $(p=0.024)$ and Microlaimus $(p=0.020)$ were indicators of the cold microhabitat. Microlaimus and Paracanthoncus appear to be indicator genera for microhabitats $C 3, C 5$ and $C 11$ in particular $(p=0.05)$. No significant meiofaunal indicator was found for the warm microhabitats.

\subsection{Beta differentiation of ecological communities}

Beta diversity computed on Hellinger-transformed data using the BDTotal index of Legendre \& De Cáceres (2013, eq. 3) was about the same for the macrofauna (0.350) and meiofauna (0.366). The maximum possible value for this index is 1 , when all sampling units contain different taxa; hence, our sites displayed about one-third of the maximum possible beta differentiation. Local indices of beta diversity (LCBD), which represent the degree of ecological uniqueness of the fauna in individual sampling units, did not exhibit a distinct pattern between warm and cold microhabitats (Fig. 6A). The indices were highest in two sampling units ( $\mathrm{C7}$ and $\mathrm{C} 8$ ) that are located in the center of the Eiffel Tower edifice on the main structure. However, species richness and alpha diversity (measured by diversity number $\mathrm{N}$, which corresponds to the Shannon index) were high in cold microhabitats (Figs. 6B-D). Macrofaunal densities were rather uniform throughout the edifice, with the warm microhabitats exhibiting the lowest densities (Fig. 6C). Although some sampling units were only separated by a few centimeters on the hydrothermal edifice, the observed patterns 
were in some cases radically different, as revealed for species richness at C4 and C11, which both represented cold microhabitats (Fig. 6c).

With the exception of C10, meiofaunal LCBD indices were higher in warm microhabitats (Fig. 7A). The highest LCBD values were found in sampling units located on the main edifice of Eiffel Tower, but they were not the same as those with high LCBD indices for the macrofauna. However, meiofaunal taxonomic richness, density and alpha diversity number $\mathrm{N}$ were all high in cold microhabitats (Figs. 7B-D). Meiofaunal densities exhibited larger variations between the different habitat types than macrofauna densities, with the warm microhabitats exhibiting the lowest densities (Fig. 7C). Although some sampling units were only separated by a few centimeters, the observed patterns were in some cases radically different, as revealed for faunal density at C2 and C8, which both represented warm microhabitats (Fig. 7C).

\section{Discussion}

This study evaluated the composition, abundance and diversity of 12 benthic faunal assemblages from various locations on the Eiffel Tower edifice on the Lucky Strike vent field (MAR) and investigated the role of key environmental conditions on the distribution of macro- and meiofaunal species. It represents one of the few attempts to conduct a complete comprehensive study of the microdistribution of hydrothermal meiofauna on a single sulfide edifice.

\subsection{Identification of microhabitats}

Three microhabitats along the dilution gradient were identified on the Eiffel Tower edifice: (1) cold microhabitats characterized by low temperatures, low TdS, high TdCu and high $\mathrm{pH}$; (2) warm microhabitats characterized by warmer temperatures, low $\mathrm{pH}$ and high TdS/TdFe concentrations; and (3) a third microhabitat characterized by intermediate abiotic conditions. Fluctuations of environmental conditions were greater in the warm microhabitats than in the cold microhabitats. Our maximum temperatures in warm microhabitats $\left(8.8 \pm 2.7^{\circ} \mathrm{C}\right)$ were in the same range as those measured by Zielinski et al. (2011) in the Logatchev mussel beds (MAR) $\left(10.9 \pm 3.4^{\circ} \mathrm{C}\right)$, and those reported at several vent sites (SEPR, EPR, Lau Basin) (reviewed by Zielinski et al. 2011). Our TdS concentrations 
$(1.50 \pm 0.9 \mu \mathrm{M}$ to $40.07 \pm 25.2 \mu \mathrm{M})$ were also in the same range as those reported in other vent mussel assemblages ( 0 to $87 \mu \mathrm{M}$ for a mean of $27 \mu \mathrm{M}$; Lutz et al., 2008; Nees et al., 2008). Abiotic conditions can vary significantly in microhabitats that are separated by only a few centimeters ( $C 2$ and $C 3$ for example, which are $50 \mathrm{~cm}$ apart), as highlighted in other vent studies (Sarrazin et al., 1997, 1999; Luther et al., 2001; Le Bris et al., 2006; Podowski et al., 2009). Consequently, the faunal patterns can be very different between closely spaced sampling units.

As expected, the distribution and abundance of the Eiffel Tower macrofauna were significantly influenced by environmental conditions, particularly by mean $\mathrm{TdCu}$ and $\mathrm{TdS}$ concentrations, and $\mathrm{pH}$ and mean temperature. These abiotic factors represent the most significant proxies to differentiate the cold and warm microhabitats. Bathymodiolus azoricus, Amathys lutzi, Branchipolynoe seepensis, Protolira valvatoides and Lepetodrilus atlanticus were identified as significant indicator taxa for the cold microhabitats, while higher abundance of Chorocaris chacei shrimp is indicative of the presence of warm microhabitats.

A narrow temperature range $\left(\sim 2.5^{\circ} \mathrm{C}\right)$ was observed between our different microhabitats/assemblages. Niche differences appear to be related to the concentrations and variation of the chemical species encountered in hydrothermal fluids, which can vary considerably over a narrow temperature gradient (Sarrazin et al., 1999; Sarradin et al., 1999, 2009; Cuvelier et al., 2009; Zielinski et al. 2011). Thus, hydrothermal animals live in the chemically reactive mixing zone between high-temperature hydrothermal fluids $\left(324^{\circ} \mathrm{C}, \mathrm{pH}\right.$ 3.5-4.2) that provide them with reduced chemicals and cold bottom seawater $\left(4.4^{\circ} \mathrm{C}, \mathrm{pH} 7.8\right)$ that carries the oxygen and oxidants they need (Johnson et al., 1988; Le Bris et al., 2006; Sarradin et al., 1999, 2009; Zielinski et al., 2011). The presence of all our assemblages in temperature conditions of $<11.5^{\circ} \mathrm{C}$ can be linked to the fact that oxygen concentrations in hydrothermal fluids are practically nil when fluid temperature exceeds ca. $10-12^{\circ} \mathrm{C}$ (Johnson et al., 1988; Zielinski et al., 2011). The surrounding environment not only provides the necessary energy sources and suspended organic particles for vent fauna nutrition (Schmidt et al., 2008), but also potentially toxic compounds such as metals (Martins et al., 2011b) and radionuclides (Charmasson et al., 2009). The presence of this oxic/anoxic interface favors the increase of $\mathrm{TdCu}$ produced by the oxidative dissolution of copper sulfide particles in cold 
microhabitats (Sarradin et al., 2009). In addition, binding and complexation of hydrothermally-derived metals $(\mathrm{Cr}, \mathrm{Cu}, \mathrm{Fe})$ to organic molecules potentially influence the stabilization, and thus the bioavailability, of metals (Sander and Koschinski, 2011). The respective role of dissolved and particulate metals in the structuring of vent assemblages requires further study, in conjunction with the trophic behavior of the fauna (Cosson et al., 2008; Sarradin et al., 2009).

The relationships between the distribution of meiofauna and environmental conditions at vents were rarely assessed (Gollner et al., 2007). Meiofaunal distribution and abundance on the Eiffel Tower edifice were significantly influenced by the same environmental factors as those significant for the macrofauna. Likewise, Gollner et al. (2007) showed significant differences in meiofaunal community structure between two tubeworm assemblages with very different chemical characteristics (especially sulfide concentrations) on the EPR. Our data also show that the distribution of copepod developmental stages was significantly influenced by environmental conditions, particularly $\mathrm{pH}$, temperature variation and TdS concentration. In addition, they indicate that nauplii, copepodids and adults do not necessarily share the same niche, as reported previously for Tegastidae (Ivanenko et al., 2011).

\subsection{Faunal patterns}

The warm microhabitats, colonized by larger mussels, were characterized by lower macro- and meiofaunal densities. On the other hand, the cold microhabitats with smaller mussels exhibited higher macro- and meiofaunal richness and diversity. Similar results have been reported in other vent studies (Sarrazin and Juniper, 1999; Sarrazin et al., 1999; Dreyer et al., 2005; Cuvelier et al., 2009). Although mussel assemblages provide complex secondary surface and interstitial habitats that favor the recruitment of several associated species (Van Dover, 2000), those from the warm microhabitats did not appear to favor a high faunal diversity. Similarly, Cuvelier et al. (2009) showed that mussel size was negatively correlated with taxonomic richness. Large mussels with enhanced nutritional requirements may inhibit the establishment of other taxa or even induce larval mortality in macrofaunal species (Dreyer et al., 2005). Moreover, the environmental conditions and their wider fluctuations in 
warm microhabitats may be too harsh to allow colonization by particular taxa (Sarrazin et al., 1997; Shank et al., 1998; Nees et al., 2008).

Sampling units with unique faunal composition and contributing the most to beta diversity increases on the Eiffel Tower were not attributed to warm or cold microhabitats, but to microhabitats located on the central part of the edifice. The latter exhibited higher beta diversity than those from the northern or southern sides (Figs. 6A, 7A). Interestingly, the Eiffel Tower edifice has the same north-south orientation than that observed for largescale current patterns (Khripounoff et al., 2008, 2009), raising questions about the role of hydrodynamic processes. We suspect they may play a fundamental role in species distribution as well as on larval dispersal (Marsh et al., 2001), contributing to divert hydrothermal fluids on the edifice surfaces. Whether the higher beta diversity is linked to local edifice topography, the presence of higher habitat heterogeneity, proximity of several active sources or to hydrodynamic factors remains to be investigated. Deep ocean currents, tides and local topography may affect the flow of diffuse fluids and thus influence its relative composition both spatially and temporally (reviewed by Zienliski et al., 2011; Cuvelier et al., 2014; Sarrazin et al., 2014).

\subsection{Community structure}

A total of 70 taxonomic groups were identified, and there was a high percentage (39\%) of "rare" species (i.e. present in 1 or 2 sampling units). An earlier study on the same edifice by Van Dover and Trask (2000) identified 20 taxa $(n=5)$, whereas Cuvelier et al. (2009) focusing only on macrofauna, sampled 15 taxa $(n=5)$. On another Lucky Strike edifice (Sintra), 25 vent macro- and meiofaunal taxa were identified in mussel assemblages, for a total of 28 species on two Lucky Strike edifices (Van Dover, 2000). The highest published estimate reports a total of 48 taxa for the entire Lucky Strike hydrothermal vent field (Fabri et al., 2011). These figures correspond to only 40 to $68 \%$ of the richness obtained in this study on a single edifice. The higher number of samples $(n=12)$ and the precise determination of macro- (especially polychaetes) and meiofaunal taxa in the present study can account for these differences. For example, only 3 copepod taxa and 1 nematode group were observed by Van Dover and Trask (2000), compared to the 11 copepod families and 13 nematode genera recorded here. The high frequency of "rare" taxa also contributes to these 
differences, emphasizing the importance of sufficient sampling effort in areas of heterogeneous abiotic conditions (Sarrazin et al., 1999; Gauthier et al., 2010). In-depth taxonomic work was necessary to determine the relative contributions of the various sampling units to beta diversity.

The sampled faunal assemblages were dominated by a small number of extremely abundant species. In $75 \%$ of the sampling units, a single taxon accounted for more than $50 \%$ of the relative faunal abundance, with the most abundant species representing 33 to $91 \%$ of the total number of individuals. Other vent sites have shown similar species distribution patterns (Sarrazin and Juniper, 1999; Van Dover and Trask, 2000; Van Dover, 2002, 2003; Matabos et al., 2011) as have intertidal zones (Seed, 1996). The meiofaunal fraction, ranging from 63 to $250 \mu \mathrm{m}$, dominated the overall faunal abundance, with two genera of nematodes (Cephalochaetosoma and Halomonhystera) dominating most sampling units. An exception was C6, which was dominated by dirivultid copepods. Similarly, mussel beds from the MAR (Zekely et al., 2006), the North Fiji Basin (Vanreusel et al., 1997) and Pacific hydrothermal sites (Southern East Pacific (SEPR) and East Pacific Rises (EPR), Copley et al., 2007) were also dominated by nematodes and often, by only one or two taxa (Vanreusel et al., 2010). Dominance by a single nematode genus was also observed in tubeworm assemblages from the EPR (Gollner et al., 2007), but nematode richness and abundance were much lower (5 genera) than those associated with mussel assemblages. Soft sediment nematode communities from the North Fiji basin exhibited the highest richness with over 30 genera (Vanreusel et al., 1997). In the light of these results, nematodes appeared to be the dominant meiofaunal group in most vent communities, with a few dominant genera. They also dominated the overall faunal abundance, underscoring their potential fundamental roles in vent communities. Therefore, it is important to include this faunal compartment when evaluating biodiversity patterns and proposing impact studies.

In this study, the meiofaunal compartment accounted for more than $60 \%$ of the faunal abundance on Eiffel Tower, whereas nematodes and copepods were not very abundant in the Van Dover and Trask study (2000). This difference can be attributed to sampling methods. The tools used to sample fauna on hard substrata in deep-sea habitats include suction samplers, arm grabs, traps and colonization devices (see review in Gauthier 
et al., 2010). Each of these tools collects a certain component of the fauna associated with the size, degree of association with the substratum and mobility of the species (Gauthier et al., 2010). Here, we combined two methods (suction sampling and ROV arm grab) on each sampling unit to improve the quality of our samples. We also added a third step (suction sampling after the arm grab) to insure cleaning of the entire sampled surface area. Preliminary results comparing the complementarity of the two methods for five faunal samples showed that $\sim 40 \%$ of the vent taxa were sampled either by suction sampler or the arm grab, and that $\sim 20 \%$ of the taxonomic richness was only sampled through suction sampling (Sarrazin et al., unpublished data). Differences in relative abundance between the two studies on the same edifice can also be attributed to sampling period because temporal changes may initiate community composition changes (Sarrazin et al., 1997; Tunnicliffe et al., 1997; Shank et al., 1998; Mullineaux et al., 2000, 2003; Cuvelier et al., 2011a). Thus, in Copley et al. (2007), the youngest mussel beds exhibited lower species richness than older ones, consistent with colonization of mussel bed habitats by nematodes over time. Differences may also simply reflect the spatial heterogeneity of environmental conditions, because the samples were taken from different areas on the edifice. Finally, other reports indicate that nematodes can dominate soft-sediment deep-sea benthos (Soltwedel, 2000), vent sediments (Dinet et al., 1988) as well as other chemosynthetic environments such as cold seeps on the Norwegian margin (Soltwedel et al., 2005).

As in other vent studies, most of the nematodes found in our samples (13 genera) have been described in other marine ecosystems (Vanreusel et al., 1997, 2010; Copley et al. 2007), indicating a low degree of endemicity at the generic level. Similar taxonomic richness was found on the EPR with 17 nematode species from 14 genera and 11 families (Copley et al., 2007). Zekely et al. (2006) report much lower nematode richness in MAR (7 species) and EPR (9 species) mussel bed samples, together with a lower richness of meiofauna on the MAR edifice (15 species versus 29 in the present study). Four genera (Microlaimus, Epsilonema, Viscosia and Enoplidae) had not been collected in previous studies of hydrothermal mussel assemblages (Vanreusel et al., 1997; Zekely et al., 2006; Copley et al., 2007). Finally, nematode genera are usually represented by a single morphospecies (Vanreusel et al., 1997, 2010; Zekely et al., 2006; Copley et al., 2007), suggesting a high level 
of endemicity at the species level. The other meiofaunal taxa represent a very low percentage of the abundance and are only represented by halacarids, ostracods and tanaids.

This study represents one of the largest collections of copepod taxa found at vents thus far: 11 families in 5 orders, with at least three new species and one new genus. We can expect that the diversity of copepods will be significantly higher than that of nematodes since the number of copepod families is comparable to that of nematode genera. In addition, we compiled significant ecological data on copepod larval and sub-adult stages. The discovery of high abundance of sub-adult copepodids and nauplii was itself original because not much is known about their distribution at vent sites, or about their life cycles (Ivanenko, 1998; Ivanenko et al., 2007, 2012). Previous assumptions suggest that copepod larval stages are located outside active hydrothermal areas, but their extremely high abundance here on the edifice suggests that the copepod community is well established and thrives in the different hydrothermal microhabitats. Ancorabolidae and Canthocamptidae found in our smallest size fraction $(63 \mu \mathrm{m})$ had not been reported at vents to date. As frequently noted at most hydrothermal sites sampled (Vanreusel et al., 1997; Zekely et al., 2006; Copley et al. 2007; Gollner et al. 2007), copepods were the second most dominant meiofaunal group after the nematodes, and even dominated in one sampling unit. Similarly, Dinet et al. (1988) and Zekely et al. (2006) reported a higher abundance and dominance of copepods in a few faunal assemblages from the EPR. Copley et al. (2007) suggested that copepods may be the initial meiofaunal colonists of vent mussel beds, being replaced by nematodes over time. Testing this hypothesis requires following the development of a newly settled mussel community over time using, for example, the tools developed for deep-sea observatories (Sarrazin et al., 2007).

The macrofaunal fraction only represented a small part of the total abundance $(<38 \%)$, and the percentage of ubiquitous species (present in 11 or 12 sampling units) was quite low ( 6\%). Four taxa (Branchipolynoe seepensis, Amathys lutzi, Bathymodiolus azoricus and Mirocaris fortunata) were present in most samples. Dominance of a few macrofaunal species is a common pattern at vents and has been reported on the MAR (Copley et al., 1997; Schmidt et al., 2008; Fabri et al., 2011), the NEPR (Sarrazin and Juniper, 1999; Tsurumi and Tunnicliffe, 2001; Urcuyo et al., 2003), the EPR (Govenar et al., 2005), the SEPR 
(Matabos et al., 2011) and the Southern Ocean (Marsh et al., 2012). Polychaetes had the highest number of species, representing half of the macrofaunal richness (20 taxa). Along with mollusks, they dominated the relative macrofaunal abundance in our samples. At Lucky Strike, in contrast, Van Dover (2002) found that mollusks rather than polychaetes were the most species-rich group and that crustaceans dominated the relative macrofaunal abundance.

Our meiofaunal densities were much higher than those reported in most vent studies (Dinet et al., 1988; Zekely et al., 2006; Gollner et al., 2007), exceeding 100 ind/10 $\mathrm{cm}^{2}$ in half of our samples but similar values have been observed in other chemosynthetic ecosystems (Olu et al., 1997). Our macrofaunal densities, varying from 2077 to $24375 \mathrm{ind} / \mathrm{m} 2$, were lower than those reported in mussel beds from the Oasis vent on the SEPR (35 $886 \mathrm{ind} / \mathrm{m} 2$, Sarrazin et al., 2006), but higher than those reported in other mussel beds along the SEPR (647 to $3959 \mathrm{ind} / \mathrm{m2}$, Matabos et al., 2011). Unfortunately, no densities were available for comparisons with other MAR mussel assemblages. The macrofaunal species richness was found to be slightly lower than that observed in SEPR vent mussel assemblage (48-52 species, Van Dover, 2002), but more or less similar to those found in the EPR (40 species, Dreyer et al., 2005) and NEPR (34-46 species, Van Dover, 2003) mussel assemblages. The higher disturbance expected on EPR sites was hypothesized to favor species diversity (Juniper and Tunnicliffe, 1997; Van Dover, 2002, 2003), but the diversity data acquired during this study calls this assumption into question.

To summarize, we confirmed the general pattern previously proposed for the Eiffel Tower edifice (Comtet and Desbruyères, 1998; Sarradin et al., 1999; Cuvelier et al., 2011a, b). Shrimp-dominated assemblages live closest to the fluid exits, followed by larger size mussels and, with increasing distance, by smaller mussel assemblages. Our diversity data from a single edifice (41 macrofaunal taxa) largely exceed those obtained in other mussel assemblages from other MAR vent sites (varying from 19 to 27 taxa, Van Dover and Doerries, 2005). As in the present study, species effort curves for previous studies of Logatchev and Lucky Strike indicate an underestimation of biodiversity. Our global diversity data (70 taxa) also surpass those obtained in mussel beds from Atlantic (Fabri et al., 2011) and Pacific vent fields (between 34 to 52 taxa, Van Dover, 2003), challenging the hypothesis of a higher 
taxonomic diversity in fast spreading rate communities (Van Dover, 1995; Juniper andTunnicliffe, 1997; Van Dover and Doerries, 2005). However, our sieve mesh size (63 $\mu \mathrm{m})$ was smaller than that $(263 \mu \mathrm{m})$ used in the Van Dover and Doerries (2005) study. Additional sampling, with similar sampling and sorting strategies, would help verify if the biological diversity, within a single type of assemblage (mussel), is higher in EPR sites. Pacific vent sites harbor a greater number of faunal assemblages visually dominated by large engineer species (tubeworms, mussels, clams, alvinellids) which may increase local diversity. Similarly, the higher diversity observed in Logatchev compared to other MAR sites ( $\sim 50$ taxa) was hypothesized to be linked to the presence of a higher number of biotopes (Gebruk et al., 2000). Diversity differences between different sites/regions/oceans may also be explained by several other factors such as the degree of stability of hydrothermal activity, spacing of vent sites, substratum types, depths, age of the system, productivity levels, variation in chemical composition of the fluids as well as the relative importance of biotic interactions (Juniper and Tunnicliffe, 1997; Van Dover, 2002; Van Dover and Doerries, 2005). Consideration of all of these factors in multivariate analyses should help identify those that act as prevalent drivers of biodiversity at vents.

\subsection{Limits of the present study and future sampling strategies}

Even though the present study is based on a relatively large sample size for this type of ecosystem, the number of sampling units $(n=12)$ is relatively low and were taken from a relatively small surface area (total of $0.6 \mathrm{~m}^{2}$ ). The evaluation of species richness depends strongly on the number of sampling units and the surface area sampled (Gauthier et al., 2010), and each new bulk sample at a given location may lead to the discovery of one or more new species (see review by Van Dover, 2011). Consequently, the percentage of "rare" taxa is constantly revised because they may only represent artifacts of limited sampling (Van Dover, 2003). The role of these rare taxa in the ecosystem is unknown but they may, at one point in the succession process, become more abundant, and more important in the community.

More faunal samples are required to accurately describe the global diversity of the Eiffel Tower edifice. In particular, mussel assemblages covered by a thick layer of bacterial mats (Cuvelier et al., 2009) were not sampled. These assemblages may harbor as-yet 
undiscovered species, especially in the meiofaunal compartment. In addition, active hydrothermal vents are subject to frequent small-scale disturbances (flow decrease/increase, biological processes) on very short time-scales (Sarrazin \& Juniper 1999; Govenar and Fisher, 2007) which may influence species composition and diversity (Van Dover, 2000), raising the question of temporality. Recurrent sampling may be essential to capture the overall diversity of a site although the mosaic of assemblages present on sulfide edifices may actually represent different successional stages (Sarrazin et al., 1997; Cuvelier et al., 2011a).

Moreover, quantitative sampling of hard substrata in the deep sea using a submersible, especially on vertical surfaces such as hydrothermal edifices, remains a major challenge. This sampling method may result in the loss of biodiversity information, particularly for highly mobile species and species that are closely associated with the substratum. Optimizing sampling efficiency, and thus optimal quantitative samples, requires new tools. Furthermore, ROV accessibility on steep relief and hazardous conditions (hydrothermal rising plumes, hot surfaces, hanging geological formations) also limit sampling zones, constraining the elaboration of random sampling designs. In the future, 3D microbathymetric maps of hydrothermal edifices should help identify the ROV-accessible areas to design more systematic sampling plans. Other factors affecting sampling include ROV pilot proficiency and ROV stability which depends on current regime.

Finally, contrarily to what was suggested for Pacific mussel assemblages (Van Dover, 2003), Bathymodiolus azoricus assemblages from the MAR may be affected by habitat loss or degradation because the rare taxa found in our samples are not likely to be abundant in other faunal assemblages that are absent from the Lucky Strike vent field. B. azoricus mussels are the only "true" engineer species in this vent field, providing microhabitats for associated species. Differences in community structure between fields and regions have to be taken into account when elaborating management strategies in the perspective of sulfide mineral exploitation near active hydrothermal vents. As mentioned by Van Dover (2011) "it is timely to look at the risk to biodiversity when mining of seafloor massive sulfides is permitted and to consider how conservation strategies might minimize or mitigate some of this risk." 


\section{Acknowledgments}

We thank the late Captain Philippe Guillemet of the R/V Pourquoi pas? and his crew for their steadfast collaboration in the success of the MoMARETO cruise. We are also grateful to the Victor6000 ROV pilots for their patience and constant support. We also warmly thank the LEP technical team for their valuable help both at sea and in the lab and JT for her help with the manuscript. This work was funded in part by the European Union EXOCET/D (FP6-GOCE-CT-2003-505342) and MARBEF (FP6-GOCE-CT-2003- 505446) projects, the ANR DeepOases (ANR06BDV005) and the GDR ECCHIS as well as by the CoML CHEsS project. This work was also supported by the "Laboratoire d'Excellence" LabexMER (ANR-10LABX-19) and co-funded by a grant from the French government under the program "Investissements d'Avenir". Research of VNI was supported by the Russian Foundation for Basic Research (grant 15-04-07554 a) and IFREMER. The English was professionally edited by Carolyn Engel-Gautier.

\section{References}

Bachraty, C., Legendre, P.,Desbruyeres, D., 2009. Biogeographic relationships among deepsea hydrothermal vent faunas at global scale. Deep-Sea Res. Part I 56(8), 1371-1378.

Bates, A.E., Tunnicliffe, V., Lee, R.W., 2005. Role of thermal conditions in habitat selection by hydrothermal vent gastropods. Mar. Ecol. Prog. Ser. 305, 1-15.

Bebianno, M.J., Company, R., Serafim, A., Camus, L., Cosson, R.P.,Fiala-Medoni, A., 2005. Antioxidant systems and lipid peroxidation in Bathymodiolus azoricus from Mid-Atlantic Ridge hydrothermal vent fields. Aquat. Toxicol. 75, 354-373.

Charmasson, S., Sarradin P.M., Le Faouder A., Agarande M., Loyen J.D., 2009. High levels of natural radioactivity in biota from deep-sea hydrothermal vents: a preliminary communication. J. Environ. Radioactivity 100(6), 522-526.

Company, R., Serafim, A., Bebianno, M.J., Cosson, R., Shillito, B., Fiala-Medioni, A. 2004. Effect of cadmium, copper and mercury on antioxidant enzyme activities and lipid peroxidation in the gills of the hydrothermal vent mussel Bathymodiolus azoricus. Mar. Environ. Res. 58(2-5), 377-381.

Company, R., Serafim, A., Cosson, R.P., Fiala-Medioni, A., Camus, L., Serrao-Santos, R.,Bebianno, M.J., 2010. Sub-lethal effects of cadmium on the antioxidant defense system of the hydrothermal vent mussel Bathymodiolus azoricus. Ecotoxicol. Environ. Safety 73(5), 788-795.

Comtet, T., Desbruyeres, D., 1998. Population structure and recruitment in mytilid bivalves from the Lucky Strike and Menez Gwen hydrothermal vent fields (37 degrees 17 ' $\mathrm{N}$ and 37 degrees 50 ' N on the Mid-Atlantic Ridge). Mar. Ecol. Prog. Ser., 163, 165-177. 
Copley, J.T.P., Flint, H.C., Ferrero, T.J., Van Dover, C.L., 2007. Diversity of melofauna and freeliving nematodes in hydrothermal vent mussel beds on the northern and southern East Pacific Rise. J. Mar. Biol. Assoc. U.K., 87(5), 1141-1152.

Copley, J.T.P., Tyler, P.A., Murton, B.J. VanDover, C.L., 1997. Spatial and interannual variation in the faunal distribution at Broken Spur vent field (29 degrees N, Mid-Atlantic Ridge). Mar. Biol., 129(4), 723-733.

Cosson, R.P., Thiebau, T.E., Company, R., Castrec-Rouelle, M., Colaco, A., Martins, I., Sarradin, P.M., Bebianno, M. J., 2008. Spatial variation of metal bioaccumulation in the hydrothermal vent mussel Bathymodiolus azoricus. Mar. Environ. Res., 65, 405-415.

Cuvelier, D., Sarrazin, J., Colaco, A., Copley, J., Desbruyeres, D., Glover, A.G., Tyler, P. Santos, R.S., 2009. Distribution and spatial variation of hydrothermal faunal assemblages at Lucky Strike (Mid-Atlantic Ridge) revealed by high-resolution video image analysis. Deep-Sea Research Part I 56(11), 2026-2040.

Cuvelier, D., Sarrazin, J., Colaço, A., Copley, J.T., Glover, A.G., Tyler, P.A., Santos, R.S., Desbruyeres, D.,2011a. Community dynamics over 14 years at the Eiffel Tower hydrothermal edifice on the Mid-Atlantic Ridge. Limnol. Oceanogr., 56(5), 1624-1640.

Cuvelier, D., Sarradin, P.M., Sarrazin, J., Colaco, A., Copley, J.T., Desbruyeres, D., Glover, A. G., Santos, R.S. and Tyler, P.A., 2011b. Hydrothermal faunal assemblages and habitat characterisation at the Eiffel Tower edifice (Lucky Strike, Mid-Atlantic Ridge). Mar. Ecol.Evol. Perspec., 32(2), 243-255.

Cuvelier, D., de Busserolles, F., Lavaud, R., Floc'h, E., Fabri, M.C., Sarradin, P.M.,Sarrazin, J., 2012. Biological data extraction from imagery - How far can we go? A case study from the Mid-Atlantic Ridge. Mar. Environ. Res. 82, 15-27.

Cuvelier, D., Legendre, P., Laes, A., Sarradin, P.M. and Sarrazin, J., 2014. Rhythms and community ynamics of a hydrothermal tubeworm assemblage at Main Endeavour Field A multidisciplinary deep-sea observatory approach. PLOS ONE 9(5), e96924: 16.

De Busserolles, F., Sarrazin, J., Gauthier, O., Gelinas, Y., Fabri, M.C., Sarradin, P.M. and Desbruyeres, D., 2009. Are spatial variations in the diets of hydrothermal fauna linked to local environmental conditions? Deep-Sea Research Part II 56(19-20), 1649-1664.

De Cáceres, M., Jansen, F., 2011. indicspecies: Functions to assess the strength and significance of relationship of species site group associations. $R$ package version 1.6.0. .

De Cáceres, M., Legendre, P., 2009. Associations between species and groups of sites: indices and statistical inference. Ecology 90, 3566-3574.

De'ath, G., 2012. mvpart: Multivariate partitioning. R package version 1.6-0.

Desbruyeres, D., Biscoito, M., Caprais, J. C., Colaco, A., Comtet, T., Crassous, P., Fouquet, Y., Khripounoff, A., Le Bris, N., Olu, K., Riso, R., Sarradin, P.M., Segonzac, M. and Vangriesheim, A., 2001. Variations in deep-sea hydrothermal vent communities on the Mid-Atlantic Ridge near the Azores plateau. Deep-Sea Research Part A 48(5), 1325-1346.

Dinet, A., Grassle, J.F. and Tunnicliffe, V., 1988. Premières observations sur la meiofauna des sites hydrothermaux de la dorsale Est-Pacifique (Guaymas, $21^{\circ} \mathrm{N}$ ) et de l'Explorer Ridge. Oceanology Acta 86(7), 14.

Dray, S., 2012. packfor: Forward selection with permutation (Canoco p. 46). R package version 0.0-8. [with contributions of P. Legendre \& G. Blanchet].

Dreyer, J.C., Knick, K.E., Flickinger, W.B., Van Dover, C.L., 2005. Development of macrofaunal community structure in mussel beds on the northern East Pacific Rise. Mar. Ecol. Prog. Ser. 302, 121-134. 
Dufrêne, M., Legendre, P., 1997. Species assemblages and indicator species: the need for a flexible asymmetrical approach. Ecol. Monogr. 67, 345-366.

Ellison, A. M., 2010. Partitioning diversity. Ecology 91, 1962-1963.

Fabri, M.C., Bargain, A., Briand, P., Gebruk, A., Fouquet, Y., Morineaux, M. and Desbruyeres, D., 2011. The hydrothermal vent community of a new deep-sea field, Ashadze- $1,12^{\circ} 58^{\prime} \mathrm{N}$ on the Mid-Atlantic Ridge. J. Mar. Biol. Assoc. U.K., 91(1), 1-13.

Fisher, C.R., Childress, J.J., Arp, A.J., Brooks, J.M., Distel, D., Favuzzi, J.A., Felbeck, H., Hessler, R., Johnson, K.S., Kennicutt, M.C., Macko, S.A., Newton, A., Powell, M.A., Somero, G.N., Soto, T., 1988. Microhabitat variation in the hydrothermal vent mussel, Bathymodiolus thermophilus, at the Rose Garden Vent on the Galapagos Rift. Deep-Sea Research Part I 35(10-11), 1769-1791.

Gauthier, O., Sarrazin, J. and Desbruyeres, D., 2010. Measure and mis-measure of species diversity in deep-sea chemosynthetic communities. Mar. Ecol. Prog. Ser. 402, 285-302.

Gebruk, A., Fabri, M.C., Briand, P. and Desbruyères, D., 2010. Community dynamics over a decadal scale at Logatchev, 14 degrees 45 ' N, Mid-Atlantic Ridge. Cahiers De Biologie Marine 51(4), 383-388.

Gebruk, A.V., Southward, E.C., Kennedy, H., Southward, A.J., 2000. Food sources, behaviour, and distribution of hydrothermal vent shrimps at the Mid-Atlantic Ridge. J. Mar. Biol. Assoc. U.K. 80(03), 485-499.

Gollner, S., Zekely, J., Govenar, B., Le Bris, N., Nemeschkal, H.L., Fisher, C.R., Bright, M., 2007. Tubeworm-associated permanent meiobenthic communities from two chemically different hydrothermal vent sites on the East Pacific Rise. Mar. Ecol. Prog. Ser. 337, 39-49.

Govenar, B., Le Bris, N., Gollner, S., Glanville, J., Aperghis, A., Hourdez, S. Fisher, C.,2005. Epifaunal community structure associated with Riftia pachyptila aggregations in chemically different hydrothermal vent habitats. Mar. Ecol. Prog. Ser. 305, 67-77.

Govenar, B., Fisher, C.R., 2007. Experimental evidence of habitat provision by aggregations of Riftia pachyptila at hydrothermal vents on the East Pacific Rise. Mar. Ecol. Evol. Perspec. 28(1), 3-14.

Hessler, R., Lonsdale, P.F., 1991. Biogeography of Mariana Trough hydrothermal vent communities. Deep Sea Research Part A 38(2), 185-199.

Hessler, R.R., Smithey, W.M., Boudrias, M.A., Keller, C.H., Lutz, R.A.,Childress, J.J., 1988. Temporal Change in Megafauna at the Rose Garden Hydrothermal Vent (Galapagos Rift Eastern Tropical Pacific). Deep-Sea Research Part A 35(10-11), 1681-\&.

Higgins, R.P., Thiel, H., 1988. Introduction to the Study of Meiofauna. Smithsonian Institution Press: Washington D.C. 488 pp.

Ivanenko, V.N., 1998. Deep-sea hydrothermal vent Copepoda (Siphonostomatoida: Dirivultidae) in plankton over the Mid-Atlantic Ridge $\left(29^{\circ} \mathrm{N}\right)$, morphology of their first copepodid stage. Zoologicheskii Zhurnal 77(11), 1249-1256.

Ivanenko, V.N., Corgosinho, P.H.C., Ferrari, F., Sarradin, P.-M., Sarrazin, J., 2011. Microhabitat distribution of Smacigastes micheli (Copepoda: Harpacticoida: Tegastidae) from deep-sea hydrothermal vents at the Mid-Atlantic Ridge, 37 degrees N (Lucky Strike), with a morphological description of its nauplius. Mar. Ecol. Evol. Perspect. 33(2): 246-256.

Ivanenko, V.N., Corgosinho, P.H.C., Ferrari, F.D., Sarradin, P.M., Sarrazin, J., 2012. Microhabitat distribution of Smacigastes micheli (Copepoda: Harpacticoida: Tegastidae) from deep-sea hydrothermal vents at the Mid-Atlantic Ridge, $37^{\circ} \mathrm{N}$ (Lucky Strike), with a morphological description of the nauplius. Mar. Ecol. 33(2), 246-256. 
Ivanenko, V.N., Defaye, D., 2004. A new genus and species of deep-sea cyclopoid (crustacea, copepoda, cyclopinidae) from the Mid-Atlantic Ridge (azores triple junction, lucky strike). Zoosystema 26(1), 37-54.

Ivanenko, V.N., Martínez Arbizu, P., Stecher, J., 2007. Lecithotrophic nauplius of the family Dirivultidae (Copepoda; Siphonostomatoida) hatched on board over the Mid-Atlantic Ridge (5ㅇ). Mar. Ecol. 28, 49-53.

Johnson, H.P., Tunnicliffe, V., 1985. Time-series measurements of hydrothermal activity on northern Juan-de-Fuca Ridge. Geophys. Res. Lett. 12(10), 685-688.

Johnson, K.S., Childress, J.J., Hessler, R.R., Sakamotoarnold, C.M., Beehler, C.L. 1988. Chemical and biological interactions in the Rose Garden Hydrothermal Vent Field, Galapagos Spreading Center. Deep-Sea Research Part A 35(10-11), 1723-1744.

Juniper, S.K., Tunnicliffe, V., 1997. Crustal accretion and the hot vent ecosystem. Philosophical Transactions of the Royal Society a-Mathematical Physical and Engineering Sciences 355(1723), 459-474.

Kelly, N., Metaxas, A., Butterfield, D., 2007. Spatial and temporal patterns of colonization by deep-sea hydrothermal vent invertebrates on the Juan de Fuca Ridge, NE Pacific. Aquat. Biol. 1(1), 1-16.

Khripounoff, A., Vangriesheim, A., Crassous, P. and Etoubleau, J., 2009. High frequency of sediment gravity flow events in the Var submarine canyon (Mediterranean Sea). Mar. Geol. 263(1-4), 1-6.

Khripounoff, A., Vangriesheim, A., Crassous, P., Segonzac, M., Lafon, V., Waren, A., 2008. Temporal variation of currents, particulate flux and organism supply at two deep-sea hydrothermal fields of the Azores Triple Junction. Deep-Sea Research Part I 55(4), 532551.

Le Bris, N., Sarradin, P.M., Caprais, J.C., 2003. Contrasted sulphide chemistries in the environment of 13 degrees N EPR vent fauna." Deep-Sea Research Part I 50(6), 737-747.

Le Bris, N., Govenar, B., Le Gall, C., Fisher, C.R., 2006. Variability of physico-chemical conditions in 9 degrees 50 'N EPR diffuse flow vent habitats. Mar. Chem. 98 (2-4), 167182.

Lee, R.W., 2003. Thermal tolerances of deep-sea hydrothermal vent animals from the Northeast Pacific. Biol. Bull. 205(2), 98-101.

Legendre, P., De Caceres, M., 2013. Beta diversity as the variance of community data: dissimilarity coefficients and partitioning. Ecol. Lett. 16 951-963.

Legendre, P., Gallagher, E.D., 2001. Ecologically meaningful transformations for ordination of species data. Oecologia 129, 271-280.

Legendre, P., Legendre, L., 2012. Numerical Ecology, 3rd Edn. Elsevier, Amsterdam.

Lenihan, H.S., Mills, S.W., Mullineaux, L.S., Peterson, C.H., Fisher, C.R., Micheli, F.. 2008. Biotic interactions at hydrothermal vents: Recruitment inhibition by the mussel Bathymodiolus thermophilus. Deep-Sea Research Part I55(12), 1707-1717.

Levesque, C., Juniper, S.K., Marcus, J., 2003. Food resource partitioning and competition among alvinellid polychaetes of Juan de Fuca Ridge hydrothermal vents. Mar. Ecol. Prog. Ser. 246, 173-182.

Levesque, C., Limen, H., Juniper, S.K., 2005. Origin, composition and nutritional quality of particulate matter at deep-sea hydrothermal vents on Axial Volcano, NE Pacific. Mar. Ecol. Prog. Ser. 289, 43-52. 
Limen, H., Levesque, C., Juniper, S.K., 2007. POM in macro-/meiofaunal food webs associated with three flow regimes at deep-sea hydrothermal vents on Axial Volcano, Juan de Fuca Ridge. Mar. Biol. 153(2), 129-139.

Luther, G.W., Rozan, T.F., Taillefert, M., Nuzzio, D.B., Di Meo, C., Shank, T.M., Lutz, R.A.. Cary, S. C., 2001. Chemical speciation drives hydrothermal vent ecology. Nature 410(6830), 813-816.

Lutz, R.A., Shank, T.M., Luther, G.W., Vetriani, C., Tolstoy, M., Nuzzio, D.B., Moore, T.S., Waldhauser, F., Crespo-Medina, M., Chatziefthimiou, A.D., Annis, E.R., Reed, A.J., 2008. Interrelationships between vent fluid chemistry, temperature, seismic activity, and biological community structure at a mussel-dominated, deep-sea hydrothermal vent along the East Pacific Rise. J.Shellfish Res. 27, 177-190.

Marsh, A.G., Mullineaux, L.S., Young, C.M., Manahan, D.T., 2001. Larval dispersal potential of the tubeworm Riftia pachyptila at deep-sea hydrothermal vents. Nature 411 (6833), 7780.

Marsh, L., Copley, J.T., Huvenne, V.A.I., Linse, K., Reid, W.D.K., Rogers, A.D., Sweeting, C.J., Tyler, P.A., 2012. Microdistribution of faunal assemblages at deep-sea hydrothermal vents in the Southern Ocean. Plos One 7(10), e48348. doi:10.1371/journal.pone.0048348.

Martins, I., Bettencourt, R., Colaco, A., Sarradin, P.M., Santos, R.S., Cosson, R., 2011a. The influence of nutritional conditions on metal uptake by the mixotrophic dual symbiosis harboring vent mussel Bathymodiolus azoricus. Comp. Biochem. Physiol. C-Toxic. Pharmacol., 153(1), 40-52.

Martins, I., Cosson, R.P., Riou, V., Sarradin, P.M., Sarrazin, J., Santos, R.S., Colaco, A. 2011b. Relationship between metal levels in the vent mussel Bathymodiolus azoricus and local microhabitat chemical characteristics of Eiffel Tower (Lucky Strike). Deep-Sea Res. Part I 58(3), 306-315.

Matabos, M., Le Bris, N., Pendlebury, S., Thiebaut, E., 2008. Role of physico-chemical environment on gastropod assemblages at hydrothermal vents on the East Pacific Rise (13 degrees N/EPR). J. Mar. Biol. Assoc. U.K. 88(5), 995-1008.

Matabos, M., Plouviez, S., Hourdez, S., Desbruyères, D., Legendre, P., Waren, A., Jollivet, D.,, Thiebaut, E., 2011. Faunal changes and geographic crypticism indicate the occurrence of a biogeographic transition zone along the southern East Pacific Rise. J. Biogeogr. 38, 575594.

Micheli, F., Peterson, C.H., Mullineaux, L.S., Fisher, C.R., Mills, S.W., Sancho, G., Johnson, G.A., Lenihan, H. S., 2002. Predation structures communities at deep-sea hydrothermal vents. Ecol. Monogr. 72(3), 365-382.

Mullineaux, L.S., Fisher, C.R., Peterson, C.H., Schaeffer, S. W., 2000. Tubeworm succession at hydrothermal vents: use of biogenic cues to reduce habitat selection error? Oecologia 123(2), 275-284.

Mullineaux, L.S., Peterson, C.H., Micheli, F., Mills, S. W., 2003. Successional mechanism varies along a gradient in hydrothermal fluid flux at deep-sea vents. Ecol. Monogr. 73(4), 523-542.

Nees, H. A., Lutz, R. A., Shank, T. M. and Luther, G. W. (2009). "Pre- and post-eruption diffuse flow variability among tubeworm habitats at $9^{\circ} 50^{\prime}$ north on the East Pacific Rise." DeepSea Research II 56: 1607-1615.

Nees, H.A., Moore, T.S., Mullaugh, K.M., Holyoke, R.R., Janzen, C.P., Shufen, M.A., Ma, S., Metzger, E., Waite, T.J., Yucel, M., Lutz, R.A., Shank, T.M., Vetriani, C., Nuzzio, D.B., 
Luther, G.W., 2008. Hydrothermal vent mussel habitat chemistry, pre- and post-eruption at $9^{\circ} 50^{\prime}$ North on the East Pacific Rise. J. Shellfish Res. 27(1), 169-175.

Nye, V., Copley, J.T., Tyler, P.A., 2013. Spatial Variation in the Population Structure and Reproductive Biology of Rimicaris hybisae (Caridea: Alvinocarididae) at Hydrothermal Vents on the Mid-Cayman Spreading Centre. Plos One 8(3), 15.

Oksanen, J., Blanchet, F.G., Kindt, R., Legendre, P., Minchin, P.R., O’Hara, R.B., Simpson, G. L., Solymos, P., Stevens, M.H.H., Wagner, H., 2012. Vegan: Community ecology package. $R$ package version 2.0-3.

Olu, K., Lance, S., Sibuet, M., Henry, P., Fiala-Medioni, A., Dinet, A., 1997. Cold seep communities as indicators of fluid expulsion patterns through mud volcanoes seaward of the Barbados Accretionary Prism. Deep Sea Res. 44, 811-841.

Podowski, E.L., Moore, T.S., Zelnio, K.A., Luther, G.W., III, Fisher, C.R., 2009. Distribution of diffuse flow megafauna in two sites on the Eastern Lau Spreading Center, Tonga. DeepSea Res. Part I 56(11), 2041-2056.

Riso, R.D., Monbet, P., Le Corre, P., 1997. Measurement of copper in sea-water by constant current stripping analysis (CCSA) with a rotating gold disk electrode. The Analyst 122, 1593-1596.

Sander, S.G., Koschinsky, A., 2011. Metal flux from hydrothermal vents increased by organic complexation. Nature Geosci. 4, 145-150.

Sarradin, P.M., Caprais J.C., Riso R., Kerouel R., 1999. Chemical environment of the hydrothermal mussel communities in the Lucky Strike and Menez Gwen vent fields, Mid Atlantic ridge. Cahiers De Biologie Marine 40(1), 93-104.

Sarradin, P.M., Waeles M., Bernagout S., Le Gall C., Sarrazin J., 2009. Speciation of dissolved copper within an active hydrothermal edifice on the Lucky Strike vent field (MAR, 37 degrees N). Sci. Total Environ. 407(2), 869-878.

Sarrazin, J., Juniper, S.K., 1999. Biological characteristics of a hydrothermal edifice mosaic community. Mar. Ecol. Prog. Ser. 185, 1-19.

Sarrazin, J., Robigou, V., Juniper, S.K., Delaney, J.R., 1997. Biological and geological dynamics over four years on a high-temperature sulfide structure at the Juan de Fuca Ridge hydrothermal observatory. Mar. Ecol. Prog. Ser. 153, 5-24.

Sarrazin, J., Juniper, S.K., Massoth, G. and Legendre, P., 1999. Physical and chemical factors influencing species distributions on hydrothermal sulfide edifices of the Juan de Fuca Ridge, northeast Pacific. Mar. Ecol. Prog. Ser. 190, 89-112.

Sarrazin, J., Levesque, C., Juniper, S.K., Tivey, M.K., 2002. Mosaic community dynamics on Juan de Fuca Ridge sulphide edifices: substratum, temperature and implications for trophic structure. Cahiers De Biologie Marine 43(3-4), 275-279.

Sarrazin, J., Walter, C., Sarradin, P.M., Brind'Amour, A., Desbruyeres, D., Briand, P., Fabri, M. C., Van Gaever, S., Vanreusel, A., Bachraty, C., Thiebaut, E., 2006a. Community structure and temperature dynamics within a mussel assemblage on the Southern East Pacific Rise." Cahiers De Biologie Marine 47(4), 483-490.

Sarrazin, J., Sarradin, P.M., MoMareto cruise participants, 2006b. MoMARETO: a cruise dedicated to the spatio-temporal dynamics and the adaptations of hydrothermal vent fauna on the Mid-Atlantic Ridge. InterRidge News 15, 24-33.

Sarrazin J., JBlandin, J., Delauney, L., Dentrecolas, S., Dorval, P., JDupont, J., Legrand, J., Leroux, D., Léon, P., Lévèque, J.P., Rodier, P., Vuillemin, R., Sarradin, P.M. 2007. TEMPO: a new ecological module for studying deep-sea community dynamics at hydrothermal Vents. MARTECH07, Conference proceedings, Instrumentation viewpoint, 6, p. 23. 
Sarrazin, J., Cuvelier, D., Peton, L., Legendre, P., Sarradin, P.M., 2014. High-resolution dynamics of a deep-sea hydrothermal mussel assemblage monitored by the EMSO-Açores MoMAR observatory". Deep-Sea Res. Part I 90: 62-75.

Schmidt, C., Le Bris, N., Gaill, F., 2008. Interactions of deep-sea vent invertebrates with their environment: the case of Rimicaris exoculata. J. Shellfish Res. 27(1): 79-90.

Seed, R., 1996. Patterns of biodiversity in the macro-invertebrate fauna associated with mussel patches on rocky shores. J. Mar. Biol. Assoc. U.K. 76, 203-210.

Seinhorst, J.W.,1959). A rapid method for the transfer of nematodes from fixative to anhydrous glycerin. Nematologica 4, 67-69.

Shank, T.M., Fornari, D.J., Von Damm, K.L., Lilley, M.D., Haymon, R.M., Lutz, R.A., 1998. Temporal and spatial patterns of biological community development at nascent deep-sea hydrothermal vents (9 degrees 50 ' N, East Pacific Rise). Deep-Sea Res Part II 45(1-3), 465+ .

Sievert, S.M., Brinkhoff, T., Muyzer, G., Ziebis, W., Kuever, J., 1999. Spatial heterogeneity of bacterial populations along an environmental gradient at a shallow submarine hydrothermal vent near Milos island (Greece). Applied Environ. Microbiol. 65, 3834-3842.

Soltwedel, T., 2000. Metazoan meiobenthos along continental margins: a review. Prog. Oceanogr. 46, 59-84.

Soltwedel, T., Bauerfeind, E., Bergmann, M., Budaeva, N., Hoste, E., Jaeckisch, N., von Juterzenka, K., Matthiessen, J., Mokievsky, V., Nöthig, E.-M., Quéric, N.-V., Sablotny, B., Sauter, E., Schewe, I., Urban-Malinga, B., Wegner, J., Wlodarska-Kowalczuk, M., Klages, M., 2005. AUSGARTEN: Multidisciplinary investigations at a deep-sea, long-term observatory in the Arctic Ocean. Oceanography 18(3), 46-61.

Tokeshi, M., 2011. Spatial structures of hydrothermal vents and vent-associated megafauna in the back-arc basin system of the Okinawa Trough, western Pacific. J. Oceanogr. 67, 651-665.

Tsurumi, M., Tunnicliffe, V., 2001. Characteristics of a hydrothermal vent assemblage on a volcanically active segment of Juan de Fuca Ridge, northeast Pacific. Can. J. Fish. Aquat. Sci. 58(3) 530-542.

Tunnicliffe, V., 198). Biogeography and evolution of hydrothermal vent fauna in the Eastern Pacific Ocean. Proc. Royal Soc. B-Biol. Sci. 233 (1272), 347-366.

Tunnicliffe, V., 1991. The biology of hydrothermal vents - Ecology and evolution. Oceanogr. Mar. Biol. 29, 319-407.

Tunnicliffe, V., Embley, R.W., Holden, J.F., Butterfield, D.A., Massoth, G.J., Juniper, S.K., 1997. Biological colonization of new hydrothermal vents following an eruption on Juan de Fuca Ridge. Deep-Sea Res. Part I 44(9-10), 1627-\&.

Urcuyo, I.A., Massoth, G.J., Julian, D., Fisher, C.R. 2003. Habitat, growth and physiological ecology of a basaltic community of Ridgeia piscesae from the Juan de Fuca Ridge. DeepSea Res. Part I 50(6), 763-780.

Van Dover, C.L., 1995. Ecology of Mid-Atlantic Ridge hydrothermal vents." Geol. Soc. 87(1), 257-294.

Van Dover, C.L., 2000. The ecology of deep-sea hydrothermal vents. Princeton University Press, Princeton, New Jersey. 424 pp.

Van Dover, C.L., 2002. Community structure of mussel beds at deep-sea hydrothermal vents. Mar. Ecol. Prog. Ser. 230, 137-158. 
Van Dover, C.L., 2003. Local, regional, and biogeographic variation in community structure within hydrothermal-vent mussel beds of the East Pacific Rise. Mar. Ecol. Prog. Ser. 253, 55-56.

Van Dover, C.L., 2011. Tighten regulations on deep-sea mining. Nature 470(7332), 31-33.

Van Dover, C.L., Doerries, M.B., 2005. Community structure in mussel beds at Logatchev hydrothermal vents and a comparison of macrofaunal species richness on slow- and fastspreading mid-ocean ridges. Mar. Ecol Evol. Perspect. 26(2), 110-120.

Van Dover, C.L., German, C.R., Speer, K.G., Parson, L.M., Vrijenhoek, R.C., 2002. Marine biology - Evolution and biogeography of deep-sea vent and seep invertebrates. Science 295(5558), 1253-1257.

Van Dover, C.L., Trask, J.L. 2000. Biodiversity in mussel beds at a deep-sea hydrothermal vent and a shallow-water intertidal site. Mar. Ecol. Prog. Ser. 195, 169-178.

Vanreusel, A., De Groote, A., Gollner, S., Bright, M., 2010. Ecology and biogeography of freeliving nematodes associated with chemosynthetic environments in the deep sea: a review. Plos One 5(8), 15.

Vanreusel, A., VandenBossche, I., Thiermann, F.,1997. Free-living marine nematodes from hydrothermal sediments: similarities with communities from diverse reduced habitats. Mar. Ecol. Prog. Ser. 157: 207-219.

Vuillemin, R., Le Roux, D., Dorval, P., Bucas, K., Sudreau, J.P., Hamon, M., Le Gall, C. and Sarradin, P.M., 2009. CHEMINI: a new in situ CHEmical MINlaturized analyzer. Deep Sea Res. I 56, 1391-1399.

Warwick, R.M., Platt, H.M., Somerfield, P.J., 1998. Free-living marine nematodes. Part. III. Monhysterids. Leiden.

Zekely, J., Van Dover, C.L., Nemeschkal, H.L., Bright, M., 2006. Hydrothermal vent meiobenthos associated with mytilid mussel aggregations from the Mid-Atlantic Ridge and the East Pacific Rise. Deep-Sea Research Part I 53(8), 1363-1378.

Zielinski, F.U., Gennerich, H.H., Borowski, C., Wenzhofer, F., Dubilier, N., 2011. In situ measurements of hydrogen sulfide, oxygen, and temperature in diffuse fluids of an ultramafic-hosted hydrothermal vent field (Logatchev, 14 degrees $45^{\prime} \mathrm{N}$, Mid-Atlantic Ridge): Implications for chemosymbiotic bathymodiolin mussels. Geochem. Geophys. Geosys. 12 (9): DOI: 10.1029/2011GC003632. 
Table 1. Mean environmental conditions in the 12 sampling units on the Tour Eiffel edifice. TdS: total dissolved sulfide, TdFe: total dissolved iron, TdCu: total dissolved copper. Adapted from De Busserolles et al. 2009 and Sarradin et al. 2009. $\mathrm{pH}$ and $\mathrm{TdCu}, \mathrm{n}=2$ to 4 samples, $\mathrm{T}^{\circ} \mathrm{C}$ measurements taken together with $\mathrm{TdS}$ and $\mathrm{TdFe}$ : in situ analyses, $\mathrm{n}=13$ to 19. A single in situ measurement last $90 \mathrm{~s}$ and temperature is measured every $5 \mathrm{~s}$ during that period. Temperatures associated with $\mathrm{Cu}$ sampling are also given. The estimated size of the sampled surface (data from Cuvelier et al. 2012) as well as mean mussel size for each sampling units are also given. Standard deviations are given in parentheses. Highest values are highlighted in bold; lowest values are shaded in gray. The second part of the table indicate the results obtained for each of the three microhabitat identified in the current study. NA : not available.

\begin{tabular}{|c|c|c|c|c|c|c|c|}
\hline Sampling units & $\mathbf{T}^{\circ} \mathbf{C}$ & pH & $\underset{\mu \mathrm{mol} \mathrm{I}^{-1}}{\operatorname{TdS}}$ & 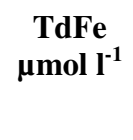 & $\begin{array}{c}\text { TdCu } \\
\mu \mathrm{mol} \mathrm{I} \mathrm{I}^{-1}\end{array}$ & $\begin{array}{c}\text { Surface } \\
\text { sampled } \\
\left(\mathrm{m}^{2}\right)\end{array}$ & $\begin{array}{c}\text { Mean } \\
\text { mussel size } \\
(\mathrm{mm})\end{array}$ \\
\hline $\mathrm{C} 1$ & $\begin{array}{c}4.91 \\
(0.47)\end{array}$ & $\begin{array}{c}6.94 \\
(0.18)\end{array}$ & $\begin{array}{c}1.50 \\
(0.90)\end{array}$ & $\begin{array}{c}0.36 \\
(0.44)\end{array}$ & $\begin{array}{c}1.56 \\
(0.87)\end{array}$ & $\begin{array}{c}0.062 \\
(0.004)\end{array}$ & $\begin{array}{c}41.74 \\
(12.92)\end{array}$ \\
\hline $\mathrm{C} 2$ & $\begin{array}{c}6.50 \\
(1.66)\end{array}$ & $\begin{array}{c}6.01 \\
(0.22)\end{array}$ & $\begin{array}{c}18.76 \\
(20.38)\end{array}$ & $\begin{array}{c}1.22 \\
(0.82)\end{array}$ & $\begin{array}{c}0.25 \\
(0.29)\end{array}$ & $\begin{array}{c}0.070 \\
(0.012)\end{array}$ & $\begin{array}{c}66.85 \\
(25.65)\end{array}$ \\
\hline $\mathrm{C} 3$ & $\begin{array}{c}5.35 \\
(0.50)\end{array}$ & $\begin{array}{c}6.72 \\
(0.20)\end{array}$ & $\begin{array}{c}3.85 \\
(2.01)\end{array}$ & $\begin{array}{c}0.36 \\
(0.19)\end{array}$ & $\begin{array}{l}1.36 \\
(0.21)\end{array}$ & $\begin{array}{l}0.082 \\
(0.00)\end{array}$ & $\begin{array}{c}50.77 \\
(12.09)\end{array}$ \\
\hline $\mathrm{C} 4$ & $\begin{array}{c}5.67 \\
(0.50)\end{array}$ & $\begin{array}{c}6.61 \\
(0.09)\end{array}$ & $\begin{array}{c}6.97 \\
(5.01)\end{array}$ & $\begin{array}{c}1.69 \\
(0.77)\end{array}$ & $\begin{array}{c}2.06 \\
(1.29)\end{array}$ & $\begin{array}{c}0.049 \\
(0.001)\end{array}$ & $\begin{array}{c}38.06 \\
(16.98)\end{array}$ \\
\hline $\mathrm{C} 5$ & $\begin{array}{c}5.11 \\
(0.48)\end{array}$ & $\begin{array}{c}6.87 \\
(0.10)\end{array}$ & $\begin{array}{c}2.13 \\
(1.00)\end{array}$ & $\begin{array}{l}0.14 \\
(0.20)\end{array}$ & $\begin{array}{c}0.80 \\
(0.42)\end{array}$ & $\begin{array}{c}0.049 \\
(0.004)\end{array}$ & $\begin{array}{c}29.17 \\
(12.72)\end{array}$ \\
\hline C6 & $\begin{array}{c}6.04 \\
(0.59)\end{array}$ & $\begin{array}{c}6.44 \\
(0.04)\end{array}$ & $\begin{array}{l}12.83 \\
(6.28)\end{array}$ & $\begin{array}{l}1.13 \\
(0.98)\end{array}$ & $\begin{array}{c}0.67 \\
(0.43)\end{array}$ & $\begin{array}{c}0.077 \\
(0.007)\end{array}$ & $59.33(8.39$ \\
\hline $\mathrm{C} 7$ & $\begin{array}{c}5.39 \\
(0.30)\end{array}$ & $\begin{array}{c}6.56 \\
(0.04)\end{array}$ & $\begin{array}{c}5.11 \\
(3.51)\end{array}$ & $\begin{array}{c}0.54 \\
(0.36)\end{array}$ & $\begin{array}{c}1.60 \\
(0.06)\end{array}$ & $\begin{array}{c}0.01 \\
(0.004)\end{array}$ & $\begin{array}{c}38.46 \\
(17.69)\end{array}$ \\
\hline $\mathrm{C} 8$ & $\begin{array}{c}7.49 \\
(1.54)\end{array}$ & $\begin{array}{l}6.03 \\
(0.38)\end{array}$ & $\begin{array}{c}38.31 \\
(11.94)\end{array}$ & $\begin{array}{c}3.53 \\
(2.67)\end{array}$ & $\begin{array}{c}1.62 \\
(1.96)\end{array}$ & $\begin{array}{c}0.028 \\
(0.002)\end{array}$ & $74.73(2.57$ \\
\hline C9 & $\begin{array}{c}4.79 \\
(0.12)\end{array}$ & $\begin{array}{c}7.34 \\
(\mathbf{0 . 1 3})\end{array}$ & $\begin{array}{c}1.68 \\
(0.51)\end{array}$ & $\begin{array}{c}0.30 \\
(0.18)\end{array}$ & $\begin{array}{c}2.38 \\
(1.37)\end{array}$ & $\begin{array}{c}0.013 \\
(0.003)\end{array}$ & NA \\
\hline $\mathrm{C} 10$ & $\begin{array}{r}8.79 \\
(2.71)\end{array}$ & $\begin{array}{c}6.00 \\
(0.38)\end{array}$ & $\begin{array}{c}40.07 \\
(25.16)\end{array}$ & $\begin{array}{c}5.25 \\
(3.60)\end{array}$ & $\begin{array}{c}0.46 \\
(0.65)\end{array}$ & $\begin{array}{c}0.061 \\
(0.006)\end{array}$ & $\begin{array}{c}55.11 \\
(21.26)\end{array}$ \\
\hline $\mathrm{C} 11$ & $\begin{array}{c}4.85 \\
(0.26)\end{array}$ & $\begin{array}{c}6.73 \\
(0.31)\end{array}$ & $\begin{array}{c}2.62 \\
(1.38)\end{array}$ & $\begin{array}{c}0.50 \\
(0.37)\end{array}$ & $\begin{array}{c}0.86 \\
(0.37)\end{array}$ & $\begin{array}{c}0.033 \\
(0.002)\end{array}$ & $\begin{array}{c}22.66 \\
(18.07)\end{array}$ \\
\hline $\mathrm{C} 12$ & $\begin{array}{c}4.80 \\
(0.33)\end{array}$ & $\begin{array}{c}7.18 \\
(0.42)\end{array}$ & $\begin{array}{c}2.67 \\
(1.22)\end{array}$ & $\begin{array}{c}0.40 \\
(0.44)\end{array}$ & $\begin{array}{c}1.96 \\
(1.80)\end{array}$ & $\begin{array}{c}0.032 \\
(0.002)\end{array}$ & $\begin{array}{c}34.15 \\
(16.32)\end{array}$ \\
\hline Microhabitats & $\mathbf{T}^{\circ} \mathbf{C}$ & pH & $\underset{\mu \mathrm{mol} \mathrm{I}^{-1}}{\operatorname{TdS}}$ & 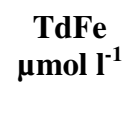 & $\begin{array}{c}\text { TdCu } \\
\mu \mathrm{mol} \mathrm{I} \mathrm{I}^{-1}\end{array}$ & $\begin{array}{c}\text { Surface } \\
\text { sampled } \\
\left(\mathrm{m}^{2}\right)\end{array}$ & $\begin{array}{c}\text { Mean } \\
\text { mussel size } \\
(\mathrm{mm})\end{array}$ \\
\hline Warm $(\mathrm{C} 2, \mathrm{C} 8, \mathrm{C} 10)$ & $\begin{array}{l}7.59 \\
(1.97)\end{array}$ & $\begin{array}{c}6.01 \\
(0.33)\end{array}$ & $\begin{array}{c}32.38 \\
(19.16)\end{array}$ & $\begin{array}{c}3.33 \\
(2.36)\end{array}$ & $\begin{array}{c}0.77 \\
(0.97)\end{array}$ & $0.05(0.02)$ & $\begin{array}{c}52.04 \\
(16.57)\end{array}$ \\
\hline Intermediate (C6) & $\begin{array}{c}6.04 \\
(0.59)\end{array}$ & $\begin{array}{c}6.44 \\
(0.04)\end{array}$ & $\begin{array}{l}12.83 \\
(6.28)\end{array}$ & $\begin{array}{l}1.13 \\
(0.98)\end{array}$ & $\begin{array}{c}0.67 \\
(0.43)\end{array}$ & 0.08 & 59.33 \\
\hline $\begin{array}{l}\text { Cold }(\mathrm{C} 1, \mathrm{C} 3, \mathrm{C} 4, \mathrm{C} 5, \mathrm{C} 7, \\
\mathrm{C} 9, \mathrm{C} 11, \mathrm{C} 12)\end{array}$ & $\begin{array}{c}5.11 \\
(0.37)\end{array}$ & $\begin{array}{c}6.87 \\
(0.18)\end{array}$ & $\begin{array}{c}3.31 \\
(1.94)\end{array}$ & $\begin{array}{c}0.54 \\
(0.37)\end{array}$ & $\begin{array}{l}1.58 \\
(0.81)\end{array}$ & $0.04(0.02)$ & $36.43(9.02$ \\
\hline
\end{tabular}

Table 2. Relative abundance of the macrofaunal taxa identified in the 12 sampling units (C1C12) distributed on the Eiffel Tower edifice. Undet= undetermined. The taxa were identified 
to the lowest taxonomical level possible. The highest abundance values are highlighted in bold.

Taxonomic groups

$$
\begin{array}{llllllllllll}
\mathrm{C} 1 & \mathrm{C} 2 & \mathrm{C} 3 & \mathrm{C} 4 & \mathrm{C} 5 & \mathrm{C} 6 & \mathrm{C} 7 & \mathrm{C} 8 & \mathrm{C} 9 & \mathrm{C} 1 & \mathrm{C} 1 & \mathrm{C} 1
\end{array}
$$

Porifera

Cnidaria-Anthozoa -

$\begin{array}{lllllllllllll}\text { Actiniaria } & 9 & & & & & \\ \text { Echinodermata-Ophiuroidea- } & 0 & 0 & 0 & 0 & 0 & 0 & 0 & 0 & 0 & 0 & 0.1 & 0.2 \\ \text { Ophiuoridae } & & & & & & & & & & 8 & 6\end{array}$

Ophiuoridae

Polychaeta

Archinome sp.

Ophryotrocha sp.

Dorvilleidae undet

Glycera tesselata

Glyceridae undet

Branchinotogluma sp.

$\begin{array}{llllllllllll}0.1 & 0 & 0 & 0 & 0 & 0 & 0 & 0.8 & 0 & 0 & 0 & 0 \\ 1 & & & & & & & 4 & & & & \\ 0 & 0 & 0.0 & 0 & 0 & 0 & 0 & 0 & 14 . & 0 & 0 & 0 \\ & & 9 & & & & & & 94 & & & \\ 0 & 0 & 0 & 0 & 0 & 0 & 0 & 0 & 0 & 0 & 0.1 & 0.2 \\ & & & & & & & & & & 8 & 6\end{array}$

Branchinotogluma fisheri

$\begin{array}{lllllllllllll}0 & 0 & 0.1 & 0 & 0 & 0 & 0 & 0 & 0 & 0 & 0 & 0 \\ 8 & & & & & & & & & & \end{array}$

Branchinotogluma mesatlantica

$\begin{array}{llllllllllll}7.1 & 0 & 1.8 & 25 . & 2.0 & 0 & 0 & 0 & 0 & 0 & 7.2 & 0 \\ 0 & & 8 & 59 & 3 & & & & & & 8 & \end{array}$

Branchipolynoe seepensis

$\begin{array}{llllllllllll}0 & 0 & 0.0 & 0 & 3.3 & 0 & 0 & 0 & 0 & 0 & 0 & 0\end{array}$

Branchipolynoe sp.

$$
\begin{array}{llllllllllll}
0.2 & 0 & 0 & 0 & 0 & 0 & 0 & 0 & 0 & 0 & 0 & 0 \\
2 & & & & & & &
\end{array}
$$$$
\begin{array}{llllllllllll}
0.1 & 0 & 0 & 0 & 0 & 0 & 0 & 0 & 0 & 0 & 0 & 0
\end{array}
$$$$
1
$$$$
\begin{array}{llllllllllll}
0.5 & 0 & 0.0 & 0 & 0 & 0 & 0 & 0 & 0 & 0 & 0 & 0
\end{array}
$$

$\begin{array}{llllllllllll}0.1 & 0 & 0 & 0 & 0 & 0 & 0 & 0 & 0 & 0 & 0 & 0.1\end{array}$

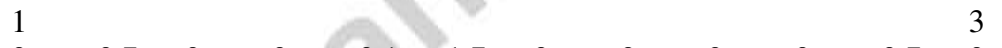

Lepidonotopodium jouinae

$\begin{array}{lllllllllll}0.7 & 0 & 0 & 0.1 & 1.7 & 0 & 0 & 0 & 0 & 0.7 & 0 \\ 6 & & & 1 & 9 & & & & & 1 & \end{array}$

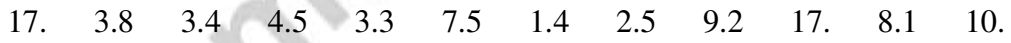

$\begin{array}{llllllllllll}63 & 0 & 0 & 9 & 2 & 3 & 2 & 2 & 0 & 76 & 7 & 64\end{array}$

$\begin{array}{llllllllllll}0 & 8.7 & 0.2 & 0 & 0 & 0 & 0 & 0 & 0 & 0 & 8.1 & 0\end{array}$

$\begin{array}{llllllllllll} & 5 & 7 & & & & & & & & \\ 0 & 0.3 & 0 & 0 & 0 & 0 & 0 & 0 & 0 & 0 & 0 & 0\end{array}$

Harmothoinae

$\begin{array}{llllllllllll}0 & 0 & 0 & 0 & 0 & 0 & 0 & 0 & 0 & 0 & 0 & 0.1\end{array}$

Lepidonotinae

$\begin{array}{llllllllllll}0 & 0 & 0.2 & 0 & 0 & 0 & 0 & 0 & 0 & 0 & 0.1 & 0\end{array}$

Polynoidae undet

$\begin{array}{llllllllllll}0.1 & 0 & 0 & 9.1 & 8.1 & 4.3 & 2.1 & 0 & 0 & 0 & 0.5 & 0\end{array}$

$\begin{array}{lllllll}1 & 7 & 4 & 0 & 3 & 0\end{array}$

Laonice asaccata

$\begin{array}{llllllllllll}0.1 & 0 & 0.0 & 0 & 0.2 & 0 & 0 & 0 & 0 & 0 & 0.1 & 0\end{array}$

Prionospio unilamellata

$\begin{array}{llllllllllll}1 & & 9 & & 1 & & & & & & 8 & \\ 0.1 & 0 & 0.1 & 0 & 0 & 0 & 0 & 0 & 0 & 0 & 0.3 & 0.1\end{array}$

$\begin{array}{llllllllllll}0.1 & 0 & 0.1 & 0 & 0 & 0 & 0 & 0 & 0 & 0 & 0.3 & 0.1 \\ 1 & & 8 & & & & & & & & 6 & 3\end{array}$

Spionidae undet

$\begin{array}{llllllllllll}0 & 0 & 0.0 & 0 & 0.7 & 0 & 0 & 0 & 0 & 0 & 0 & 0.5 \\ & & 9 & & 5 & & & & & & & 1\end{array}$

Amathys lutzi

$\begin{array}{llllllllllll}13 . & 14 . & 68 . & 23 . & 29 . & 2.1 & 0.7 & 3.3 & 6.9 & 9.2 & 10 . & 47 .\end{array}$

$\begin{array}{llllllllllll}64 & 07 & \mathbf{4 5} & 37 & 87 & 5 & 1 & 6 & 0 & 7 & 30 & \mathbf{5 6}\end{array}$

Ampharetidae undet

$\begin{array}{llllllllllll}0 & 0 & 0 & 0 & 0.1 & 0 & 0 & 0 & 0 & 0 & 0 & 0\end{array}$

Polychaeta undet

Hirudinea

$\begin{array}{llllllllllll}0.5 & 0 & 0.0 & 0 & 0 & 0 & 0 & 0 & 0 & 0 & 0 & 0.3\end{array}$

$\begin{array}{llllllllllll}5 & & 9 & & & & & & & \\ 0 & 0 & 0 & 0 & 0.1 & 0 & 0 & 0 & 0 & 0 & 0 & 0.1\end{array}$

Bivalvia-Mytilidae

Bathymodiolus azoricus

38. 22. $15 . \quad 27 . \quad 41 . \quad 21 . \quad 8.5 \quad 5.0$

35. 34. 28. 34.

Gastropoda

$\begin{array}{llllllllllll}\mathbf{8 0} & 81 & 01 & \mathbf{3 7} & \mathbf{2 2} & 86 & 1 & 4 & \mathbf{2 5} & \mathbf{7 5} & \mathbf{9 5} & 87\end{array}$


Caenogastropoda - Rissoidea-

\section{Elachisinideae}

Laeviphitus desbruyeresi

Lepetodrilus atlanticus

Lurifax vitreus

Peltospira smaragdina

Pseudorimula midatlantica

Archaeogastropoda

Lirapex costellata

Protolira valvatoides

Shinkailepas briandi

Nemerta

\section{Crustacea}

Amphipoda

Isopoda

\section{Decapoda-Bresilioidea}

\section{Alvinocarididae}

Mirocaris fortunata

Chorocaris chacei

Alvinocarididae undet

Decapoda-Brachiura

Segonzacia mesantlantica

Arthropoda-Chelicerata

Pycnogonida

$\begin{array}{llllllllllll}0 & 0 & 0 & 0.5 & 0 & 0 & 0 & 0 & 0 & 0 & 0.1 & 0 \\ 4.8 & 0.3 & 1.7 & 1.7 & 1.3 & 0 & 1.4 & 0 & 0 & 0 & 1.6 & 2.3 \\ 8 & 8 & 9 & 8 & 9 & & 2 & & & & 0 & 1 \\ 0.1 & 0 & 0 & 0 & 0.1 & 0 & 0 & 0 & 1.9 & 0 & 0 & 0 \\ 1 & & & & 1 & & & & 2 & & & \\ 0 & 0 & 0 & 0 & 0 & 0.3 & 0 & 0.8 & 0 & 0 & 0 & 0 \\ & & & & & 6 & & 4 & & & & \\ 1.4 & 0 & 0.6 & 0.4 & 0.1 & 0.3 & 0 & 0.8 & 0.3 & 0 & 2.6 & 0.7 \\ 4 & & 3 & 4 & 1 & 6 & & 4 & 8 & & 6 & 7 \\ & & & & & & & & & & & \\ 0.5 & 0 & 0 & 0 & 0.6 & 0 & 0 & 0 & 8.0 & 0 & 0.5 & 0 \\ 5 & & & & 4 & & & & 5 & & 3 & \\ 10 . & 0.3 & 1.8 & 2.9 & 3.7 & 0 & 0 & 0 & 19 . & 0 & 21 . & 1.1 \\ 09 & 8 & 8 & 6 & 5 & & & & 54 & & 31 & 5 \\ 0.1 & 0.3 & 0 & 0 & 0 & 0 & 7.8 & 0.8 & 0 & 0 & 0 & 0 \\ 1 & 8 & & & & & 0 & 4 & & & & \\ 0 & 0 & 0.5 & 0 & 0.7 & 0 & 0 & 0 & 0 & 0 & 1.0 & 0.1 \\ & & 4 & & 5 & & & & & & 7 & 3 \\ 1.2 & 0 & 0 & 0.8 & 3.9 & 23 . & 0.7 & 0.8 & 1.5 & 4.6 & 1.9 & 0.1 \\ 2 & & & 9 & 6 & 66 & 1 & 4 & 3 & 3 & 5 & 3 \\ 0 & 0 & 0 & 0 & 0 & 0 & 0 & 0 & 0 & 0 & 0.1 & 0 \\ & & & & & & & & & & 8 & \end{array}$


Table 3. Global characteristics of the macrofaunal $(>250 \mu \mathrm{m})$ communities in the 12 sampling units (C1-C12) sampled on the Tour Eiffel edifice. The highest values are highlighted in bold.

\begin{tabular}{|c|c|c|c|c|c|c|c|c|}
\hline $\begin{array}{l}\text { Sampling } \\
\text { units }\end{array}$ & $\begin{array}{c}\text { Total } \\
\text { number of } \\
\text { individuals }\end{array}$ & $\begin{array}{c}\text { Total } \\
\text { densities } \\
\text { (ind. } \mathrm{m}^{-} \\
2 \text { ) }\end{array}$ & $\begin{array}{c}\text { Estimated } \\
\text { taxonomic } \\
\text { richness }\end{array}$ & $\begin{array}{c}\text { Total } \\
\text { number of } \\
\text { polychaete } \\
\text { taxa }\end{array}$ & $\begin{array}{c}\text { Total } \\
\text { number } \\
\text { of } \\
\text { gastropod } \\
\text { taxa }\end{array}$ & $\begin{array}{l}\text { Relative } \\
\text { polychaete } \\
\text { abundance } \\
(\%)\end{array}$ & $\begin{array}{c}\text { Relative } \\
\text { mytilid } \\
\text { abundance } \\
(\%)\end{array}$ & $\begin{array}{l}\text { Relative } \\
\text { alvinocaridid } \\
\text { abundance } \\
(\%)\end{array}$ \\
\hline $\mathrm{C} 1$ & 902 & 14387 & 22 & 11 & 6 & 40.2 & 38.8 & 2.2 \\
\hline $\mathrm{C} 2$ & 263 & 3757 & 13 & 5 & 3 & 27.8 & 22.8 & 46.4 \\
\hline C3 & 1119 & 13646 & 23 & 12 & 3 & 75.1 & 15.0 & 4.2 \\
\hline $\mathrm{C} 4$ & 676 & 13796 & 13 & 4 & 4 & 62.7 & 27.4 & 3.3 \\
\hline C5 & 934 & 19061 & 19 & 9 & 5 & 47.9 & 41.2 & 0.0 \\
\hline C6 & 279 & 3623 & 11 & 4 & 2 & 15.8 & 21.9 & 36.9 \\
\hline C7 & 141 & 14100 & 8 & 3 & 2 & 4.3 & 8.5 & 77.3 \\
\hline $\mathrm{C} 8$ & 119 & 4250 & 11 & 2 & 3 & 5.9 & 5.0 & 82.4 \\
\hline C9 & 261 & 2077 & 12 & 2 & 4 & 16.1 & 35.2 & 0.4 \\
\hline $\mathrm{C} 10$ & 259 & 4246 & 7 & 2 & 0 & 27.0 & 34.7 & 33.6 \\
\hline C11 & 563 & 17061 & 23 & 9 & 5 & 35.9 & 29.0 & 4.1 \\
\hline $\mathrm{C} 12$ & 780 & 24375 & 18 & 7 & 3 & 59.5 & 34.9 & 0.5 \\
\hline Total & 6296 & & 41 & 20 & 8 & 3 & & \\
\hline
\end{tabular}

Table 4. Relative abundance of the different meiofaunal taxa $(>250 \mu \mathrm{m})$ identified in the 12 sampling units (C1-C12) on the Eiffel Tower edifice. The taxa were identified at the lowest taxonomical level possible. Highest abundances are highlighted in bold.

\begin{tabular}{|c|c|c|c|c|c|c|c|c|c|c|c|c|}
\hline Taxonomic groups & $\mathrm{C1}$ & $\mathrm{C2}$ & C3 & C4 & C5 & C6 & C7 & C8 & C9 & $\mathrm{C10}$ & C11 & C12 \\
\hline \multicolumn{13}{|c|}{ Arthropoda-Chelicerata } \\
\hline Acari-Halacaridae & 0 & 0 & 0.07 & 0.01 & 0 & 0 & 0 & 0 & 0 & 0 & 0.02 & 0 \\
\hline \multicolumn{13}{|c|}{ Arthropoda-Crustacea } \\
\hline Ostracoda & 0.07 & 0.10 & 0.08 & 0.06 & 0.01 & 3.99 & 2.19 & 0 & 0 & 3.26 & 0.22 & 0.04 \\
\hline Tanaidacea & 0.02 & 0 & 0 & 0 & 0 & 0 & 0 & 0 & 1.52 & 0 & 0.02 & 0.01 \\
\hline \multicolumn{13}{|l|}{ Nematoda } \\
\hline Halomohystera & 7.68 & 94.66 & 3.27 & 11.69 & 4.33 & 20.15 & 86.44 & 83.93 & 12.19 & $\mathbf{5 7 . 3 8}$ & 10.20 & 0.96 \\
\hline Cephalochaetosoma & 83.48 & 0 & 51.89 & 67.96 & 34.17 & 4.13 & 4.84 & 3.09 & 50.24 & 22.85 & 47.28 & 89.85 \\
\hline Leptolaimus & 0.48 & 0.46 & 17.30 & 0 & 19.03 & 0 & 1.21 & 0 & 0.74 & 6.32 & 7.88 & 0 \\
\hline Paracanthonchus & 2.88 & 0 & 1.87 & 0.87 & 3.46 & 0 & 0 & 1.23 & 4.06 & 0.49 & 1.85 & 0.96 \\
\hline Desmodora & 0 & 0 & 6.08 & 0.87 & 9.52 & 0 & 0 & 0.62 & 2.22 & 0.97 & 6.95 & 0 \\
\hline Microlaimus & 2.88 & 0 & 3.27 & 2.16 & 16.87 & 0.24 & 1.21 & 0.62 & 21.43 & 2.92 & 16.69 & 1.91 \\
\hline Chromadorita & 0 & 0 & 9.35 & 3.46 & 3.46 & 0 & 0 & 0 & 0.74 & 4.86 & 3.71 & 4.78 \\
\hline Epsilonema & 0 & 0 & 0 & 0 & 0 & 0 & 0 & 0 & 4.43 & 0 & 0 & 0 \\
\hline Syringolaimus & 0 & 0 & 0 & 0 & 0.43 & 0 & 0.60 & 0 & 0 & 0 & 2.78 & 0 \\
\hline Viscosia & 0 & 0 & 0 & 0 & 0 & 0 & 0 & 0 & 0.37 & 0 & 0 & 0 \\
\hline Theristus & 0 & 0 & 0 & 0 & 0 & 0 & 0 & 0 & 1.85 & 0 & 0 & 0 \\
\hline Calomicrolaimus & 0 & 0 & 0 & 0 & 0 & 0 & 0 & 0 & 0 & 0.49 & 0 & 0 \\
\hline Enoplidae & 0 & 0 & 0 & 0 & 0 & 0 & 0 & 0.62 & 0 & 0 & 0 & 0 \\
\hline Nematoda undet. & 0.01 & 0 & 0.77 & 0 & 0.47 & 0 & 0 & 0 & 0 & 0 & 0.33 & 0.30 \\
\hline
\end{tabular}




\section{Copepoda}

\section{Calanoida}

Spinocalanoida

$\begin{array}{llllllllllll}0.01 & 0 & 0 & 0 & 0 & 0 & 0 & 0 & 0 & 0 & 0 & 0\end{array}$

Cycloipoida

Cyclopinidae

Oithonidae

$\begin{array}{llllllllllll}0.05 & 0 & 0.39 & 0.42 & 0.47 & 0 & 0 & 0 & 0 & 0 & 0.03 & 0.23 \\ 0 & 0 & 0 & 0 & 0 & 0 & 0 & 0 & 0 & 0 & 0 & 0\end{array}$

\section{Harpacticoida}

Aegisthidae

Ectinosomatidae

Miraciidae

Pseudotachidiidae

Tegastidae

Tisbidae

Poecilostomatoida

Lubbockiidae

$\begin{array}{llllllllllll}0 & 0 & 0 & 0 & 0 & 0 & 0 & 0 & 0 & 0 & 0.01 & 0 \\ 0 & 0 & 0 & 0 & 0.01 & 0 & 0.44 & 0 & 0 & 0 & 0 & 0 \\ 0.19 & 1.20 & 0.56 & 0.09 & 0.16 & 1.14 & 0 & 0 & 0 & 0 & 0.05 & 0.08 \\ 0.03 & 0.08 & 0.01 & 0.06 & 0 & 0 & 0 & 0 & 0 & 0 & 0 & 0.01 \\ 0.10 & 0.02 & 4.89 & 6.58 & 7.54 & 0.46 & 0 & 0.52 & 0 & 0 & 0.63 & 0.85 \\ 0 & 0 & 0 & 0.59 & 0.02 & 0 & 0 & 0 & 0 & 0.16 & 0 & 0\end{array}$

Siphonostomatoida

Dirivultidae

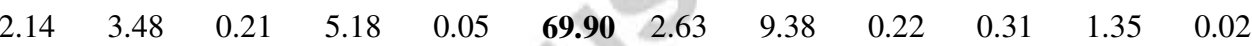

Copepoda undet.

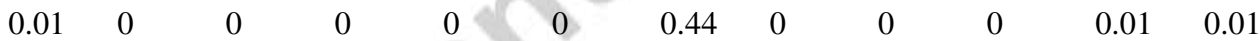


Table 5. Global characteristics of the meiofaunal $(<250 \mu \mathrm{M}$ and $>63 \mu \mathrm{M})$ communities in the twelve sampling units (C1-C12) sampled on the Tour Eiffel edifice. Highest values are highlighted in bold.

\begin{tabular}{|c|c|c|c|c|c|c|c|c|c|c|}
\hline $\begin{array}{l}\text { Sampli } \\
\text { ng units }\end{array}$ & $\begin{array}{c}\text { Total } \\
\text { number } \\
\text { of } \\
\text { individua } \\
\text { ls }\end{array}$ & $\begin{array}{c}\text { Total } \\
\text { number } \\
\text { of } \\
\text { nematod } \\
\mathrm{e} \\
\text { individua } \\
\text { ls }\end{array}$ & $\begin{array}{c}\text { Total } \\
\text { number } \\
\text { of } \\
\text { copepod } \\
\text { individua } \\
\text { ls }\end{array}$ & $\begin{array}{c}\text { Total } \\
\text { densiti } \\
\text { es (ind. } \\
\mathrm{m}^{-2} \text { ) }\end{array}$ & $\begin{array}{l}\text { Estimate } \\
\text { d } \\
\text { taxonom } \\
\text { ic } \\
\text { richness }\end{array}$ & $\begin{array}{c}\text { Total } \\
\text { number } \\
\text { of } \\
\text { nemato } \\
\text { de taxa }\end{array}$ & $\begin{array}{l}\text { Total } \\
\text { numbe } \\
\text { r of } \\
\text { copepo } \\
\text { d taxa }\end{array}$ & $\begin{array}{c}\text { Total } \\
\text { numb } \\
\text { er of } \\
\text { other } \\
\text { taxa }\end{array}$ & $\begin{array}{c}\text { Relative } \\
\text { nematod } \\
\text { e } \\
\text { abundan } \\
\text { ce }(\%)\end{array}$ & $\begin{array}{c}\text { Relative } \\
\text { copepod } \\
\text { abundan } \\
\text { ce }(\%)\end{array}$ \\
\hline $\mathrm{C} 1$ & 19529 & 19038 & 491 & $\begin{array}{l}314 \\
984\end{array}$ & 15 & 6 & 7 & 2 & 97.5 & 2.5 \\
\hline $\mathrm{C} 2$ & 6235 & 5937 & 298 & 89071 & 7 & 2 & 4 & 1 & 95.2 & 4.8 \\
\hline C3 & 56859 & 53417 & 3442 & $\begin{array}{l}693 \\
402\end{array}$ & 18 & 8 & 7 & 3 & 93.9 & 6.1 \\
\hline $\mathrm{C} 4$ & 7917 & 6894 & 1023 & $\begin{array}{l}161 \\
571\end{array}$ & 14 & 6 & 6 & 2 & 87.1 & 12.9 \\
\hline $\mathrm{C} 5$ & 36605 & 33586 & 3019 & $\begin{array}{l}747 \\
041\end{array}$ & 16 & 9 & 6 & & 91.8 & 8.2 \\
\hline C6 & 877 & 250 & 627 & 11390 & 7 & 3 & 3 & 1 & 28.5 & 71.5 \\
\hline $\mathrm{C} 7$ & 228 & 220 & 8 & 22800 & 9 & 5 & 3 & 1 & 96.5 & 3.5 \\
\hline $\mathrm{C} 8$ & 192 & 173 & 19 & 6857 & 8 & 6 & 2 & 0 & 90.1 & 9.9 \\
\hline C9 & 920 & 918 & 2 & 70769 & 12 & 10 & 1 & 1 & 99.8 & 0.2 \\
\hline $\mathrm{C} 10$ & 645 & 642 & 3 & 10574 & 11 & 8 & 2 & 1 & 99.5 & 0.5 \\
\hline $\mathrm{C} 11$ & 11039 & 10810 & 229 & $\begin{array}{l}334 \\
515\end{array}$ & 19 & 9 & 7 & 3 & 97.9 & 2.1 \\
\hline $\mathrm{C} 12$ & 16210 & 16016 & 194 & $\begin{array}{l}506 \\
563\end{array}$ & 14 & 6 & 6 & 2 & 98.8 & 1.2 \\
\hline Total & 157256 & 147901 & 9355 & & 29 & 14 & 12 & 3 & & \\
\hline
\end{tabular}

Table 6. Presence/absence of sub-adult/nauplii $(<250 \mu \mathrm{m}$ and $>63 \mu \mathrm{m})$ of different copepod families in the 12 sampling units $(\mathrm{C} 1-\mathrm{C} 12)$ on the Tour Eiffel edifice.

\begin{tabular}{|c|c|c|c|c|c|c|c|c|c|c|c|c|c|}
\hline \multirow[t]{2}{*}{ Copepod families } & \multirow[t]{2}{*}{ Stages } & $\mathbf{C}$ & $\mathbf{C}$ & $\mathbf{C}$ & $\mathbf{C}$ & $\mathbf{C}$ & $\mathbf{C}$ & $\mathbf{C}$ & $\mathbf{C}$ & $\mathbf{C}$ & C1 & C1 & C1 \\
\hline & & 1 & 2 & 3 & 4 & 5 & 6 & 7 & 8 & 9 & $\mathbf{0}$ & 1 & 2 \\
\hline Ancorabolidae (Lobopleura) & Copepodi & 1 & 0 & 0 & 1 & 1 & 0 & 0 & 0 & 1 & 1 & 1 & 1 \\
\hline Calanoida & Copepodi & 0 & 0 & 0 & 0 & 0 & 0 & 0 & 0 & 0 & 1 & 0 & 1 \\
\hline \multirow[t]{2}{*}{ Copepoda undet. } & Copepodi & 0 & 0 & 0 & 0 & 0 & 0 & 0 & 1 & 1 & 0 & 0 & 0 \\
\hline & Nauplii & 1 & 1 & 1 & 1 & 1 & 1 & 1 & 1 & 1 & 1 & 1 & 1 \\
\hline \multirow[t]{2}{*}{$\begin{array}{l}\text { Canthocamptidae (close to } \\
\text { Mesochra) }\end{array}$} & $\begin{array}{l}\text { Copepodi } \\
\text { ds }\end{array}$ & 0 & 1 & 1 & 1 & 0 & 1 & 0 & 0 & 0 & 1 & 1 & 0 \\
\hline & Nauplii & 1 & 1 & 0 & 1 & 1 & 1 & 1 & 0 & 0 & 0 & 1 & 1 \\
\hline Cyclopinidae & $\begin{array}{l}\text { Copepodi } \\
\text { ds }\end{array}$ & 0 & 0 & 0 & 0 & 0 & 0 & 0 & 0 & 1 & 0 & 1 & 1 \\
\hline \multirow[t]{2}{*}{ Dirivultidae } & $\begin{array}{l}\text { Copepodi } \\
\text { ds }\end{array}$ & 1 & 1 & 1 & 1 & 1 & 1 & 1 & 1 & 0 & 1 & 1 & 1 \\
\hline & Nauplii & 0 & 1 & 0 & 1 & 0 & 1 & 0 & 0 & 0 & 1 & 1 & 0 \\
\hline Ectinosomatidae & $\begin{array}{l}\text { Copepodi } \\
\text { ds }\end{array}$ & 0 & 0 & 1 & 0 & 1 & 0 & 0 & 0 & 0 & 0 & 0 & 1 \\
\hline \multirow[t]{2}{*}{ Miraciidae (cf Amphiascus) } & $\begin{array}{l}\text { Copepodi } \\
\text { ds }\end{array}$ & 1 & 1 & 1 & 1 & 1 & 1 & 0 & 0 & 0 & 0 & 1 & 1 \\
\hline & Nauplii & 1 & 1 & 1 & 1 & 1 & 1 & 1 & 0 & 1 & 1 & 1 & 1 \\
\hline Pseudotachidiidae (Xylora) & $\begin{array}{l}\text { Copepodi } \\
\text { ds }\end{array}$ & 0 & 1 & 1 & 1 & 1 & 1 & 1 & 0 & 0 & 1 & 1 & 1 \\
\hline
\end{tabular}


Tegastidae (Smacigastes)

Tisbidae (Tisbe)

\begin{tabular}{|c|c|c|c|c|c|c|c|c|c|c|c|}
\hline Nauplii & 0 & 1 & 0 & 0 & 0 & 0 & 0 & 0 & 0 & 1 & 0 \\
\hline $\begin{array}{l}\text { Copepodi } \\
\text { ds }\end{array}$ & 1 & 0 & 1 & 1 & 1 & 1 & 1 & 1 & 1 & 1 & 1 \\
\hline Nauplii & 1 & 0 & 1 & 1 & 1 & 1 & 0 & 0 & 1 & 0 & 1 \\
\hline $\begin{array}{l}\text { Copepodi } \\
\text { ds }\end{array}$ & 0 & 0 & 0 & 1 & 1 & 1 & 1 & 1 & 0 & 1 & 0 \\
\hline
\end{tabular}




\section{Figure captions -Sarrazin et al.}

Fig. 1. (A) Location of the Lucky Strike vent field on the Mid-Atlantic Ridge at $37^{\circ} 17.59 \mathrm{~N}$, $32^{\circ} 169 \mathrm{~W}$. Data from Amante and Eakins (2009). (B) High-resolution bathymetric map of the Eiffel Tower active hydrothermal edifice and location of the 12 sampling units (C1-C12). The $11 \mathrm{~m}$ high sulfide structure is located in the Lucky Strike vent field $\left(37^{\circ} 17.29^{\prime} \mathrm{N}, 32^{\circ} 16.45^{\prime} \mathrm{W}\right)$ on the Mid-Atlantic Ridge, south of the Azores.

Fig. 2. Principal component analysis (PCA) of the environmental variables [mean dissolved copper (Cu.mean) and sulfide (S.mean), mean temperature (Tc.mean) and mean $\mathrm{pH}$ (pH.mean)] measured on the 12 sampling units (C1-C12) studied on the Eiffel Tower edifice. The first axis explains $78.2 \%$ of the variance in the environmental data while axis 3 explains $3.2 \%$. The sampling units on the left-hand side represent cold microhabitats while those on the right-hand side represent warm microhabitats. C6 represents an intermediate microhabitat.

Fig. 3. Canonical redundancy analysis (RDA, scaling type 2) of Hellinger-transformed relative macrofaunal densities observed in the 12 sampling units (C1-C12) distributed on the Eiffel Tower edifice, as a function of a gradient of environmental conditions represented by two significant axes of the environmental PCA (Fig. 2). The first canonical axis represents $33.02 \%$ of the total variance in macrofaunal abundance while the second axis represents $5.97 \%$ (with an adjusted cumulated $R^{2}$ of 0.254 ). The $p$-value associated with this RDA is 0.0116 . Only the names of the species that showed good fit with the first two canonical axes (fitted value > 0.30) were kept in the plot. Significant indicator species, representing either the cold (lefthand side) or the warm (right-hand side) microhabitat, are underlined.

Fig. 4. Canonical redundancy analysis (RDA, scaling type 2) of Hellinger-transformed relative meiofaunal densities on the 12 sampling units (C1-C12) distributed on the Eiffel Tower edifice, as a function of a gradient of environmental conditions represented by the first significant axis of the environmental PCA (Fig. 2). The first canonical axis represents $31.6 \%$ of the total variance in meiofaunal abundance (with an adjusted $R^{2}$ of 0.25 ). The $p$-value associated with this RDA is 0.0122 . Only the names of the species that showed good fit with the single canonical axis (fitted value $>0.20$ ) were kept in the plot. Significant indicator species, here representing the cold microhabitat, are underlined.

Fig. 5. Canonical redundancy analysis (RDA, scaling type 2) of Hellinger-transformed presence/absence of copepod nauplii $(\mathrm{N}$ ) and copepodids ( $\mathrm{C}$; see Table 4 for complete taxon names) on the 12 sampling units (C1-C12) distributed on the Eiffel Tower edifice, as a function of the most significant environmental conditions: mean $\mathrm{pH}$ ( $\mathrm{pH}$. mean), mean dissolved sulfide concentrations (S.mean) and temperature variations (Tc.Delta). The first canonical axis represents $25.6 \%$ of the total variance in the distribution of copepod nauplii and copepodids while the second axis represents $22.1 \%$ (with an adjusted $R^{2}$ of 0.40 ). The $p$ value associated with this RDA is 0.0001 . 
Fig. 6. Distribution of macrofaunal (A) local contributions to $\beta$-diversity (LCBD), (B) species richness, (C) faunal density and (D) the diversity number $N$ corresponding to the Shannon diversity index $(N=\exp (H))$ among the twelve sampling units (C1-C12) on the Eiffel Tower edifice. The position of the circles was plotted using the exact $x$ (longitude) and $y$ (latitude) coordinates on the Eiffel Tower edifice (Lucky Strike vent field, MAR). The larger the size, the more influence the variable has. Blue circles represent the cold microhabitats, the grey circle represents the intermediate microhabitat while the red circles represent the warm microhabitats.

Fig. 7. Distribution of meiofaunal (A) local contributions to $\beta$-diversity (LCBD), (B) species richness, (C) faunal density and (D) diversity number $N$ among the twelve sampling units (C1C12) on the Eiffel Tower edifice. The position of the circles was plotted using the exact $x$ (longitude) and y (latitude) coordinates on the Eiffel Tower edifice (Lucky Strike vent field, MAR). The larger the size, the more influence the variable has. The blue circles represent cold microhabitats, the grey circle represents the intermediate microhabitat, while the red circles represent the warm microhabitats.

\section{Supplementary material}

Fig S1. Overview of the 12 sampling units and the delineation of the surface sampled, showing the assemblages and the habitats. Each chain link is $9 \mathrm{~cm}$ long. C12 is a bit blurry due to rising shimmering water in front of the camera lens. Figure from Cuvelier et al. 2012. 


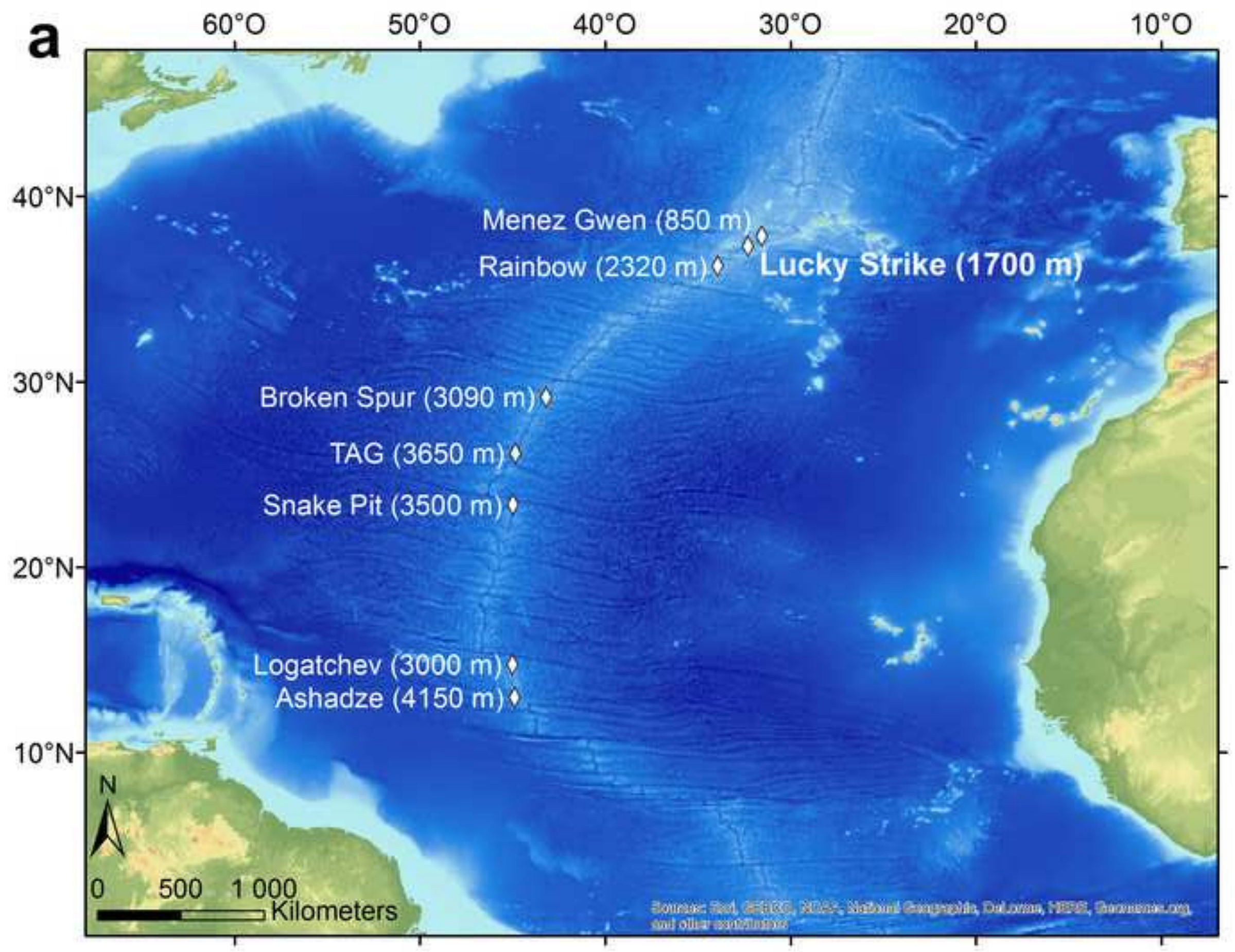



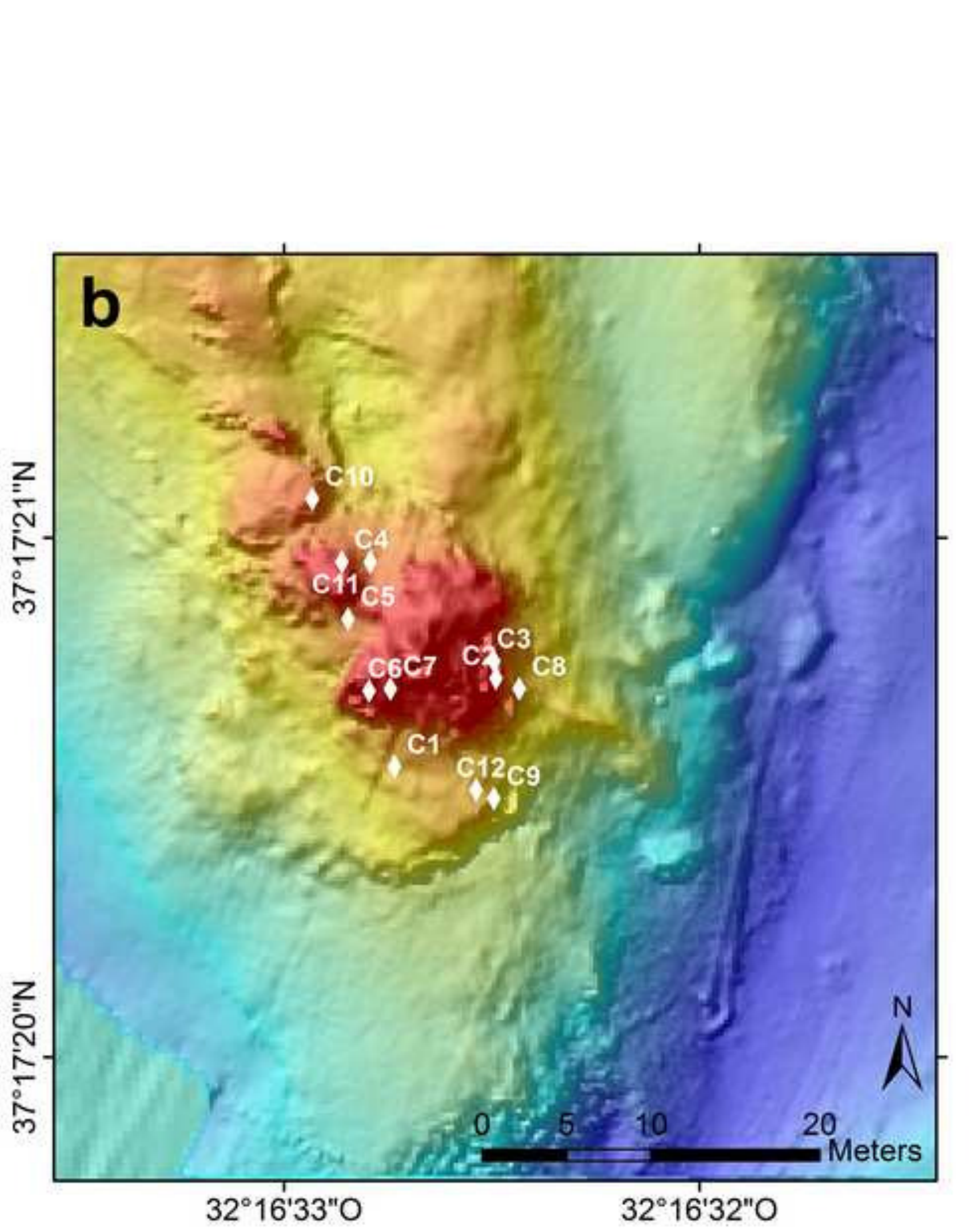

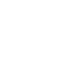




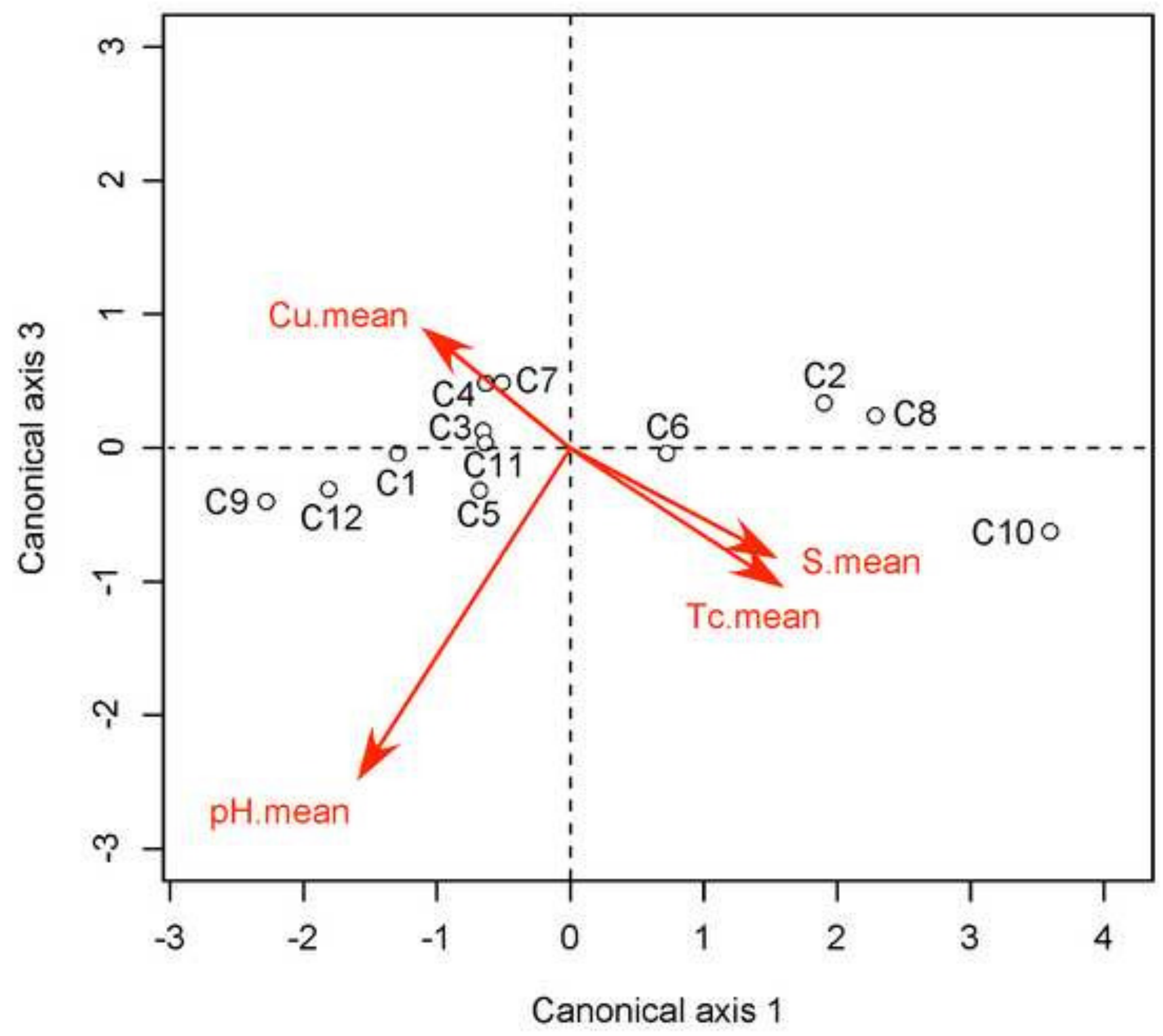




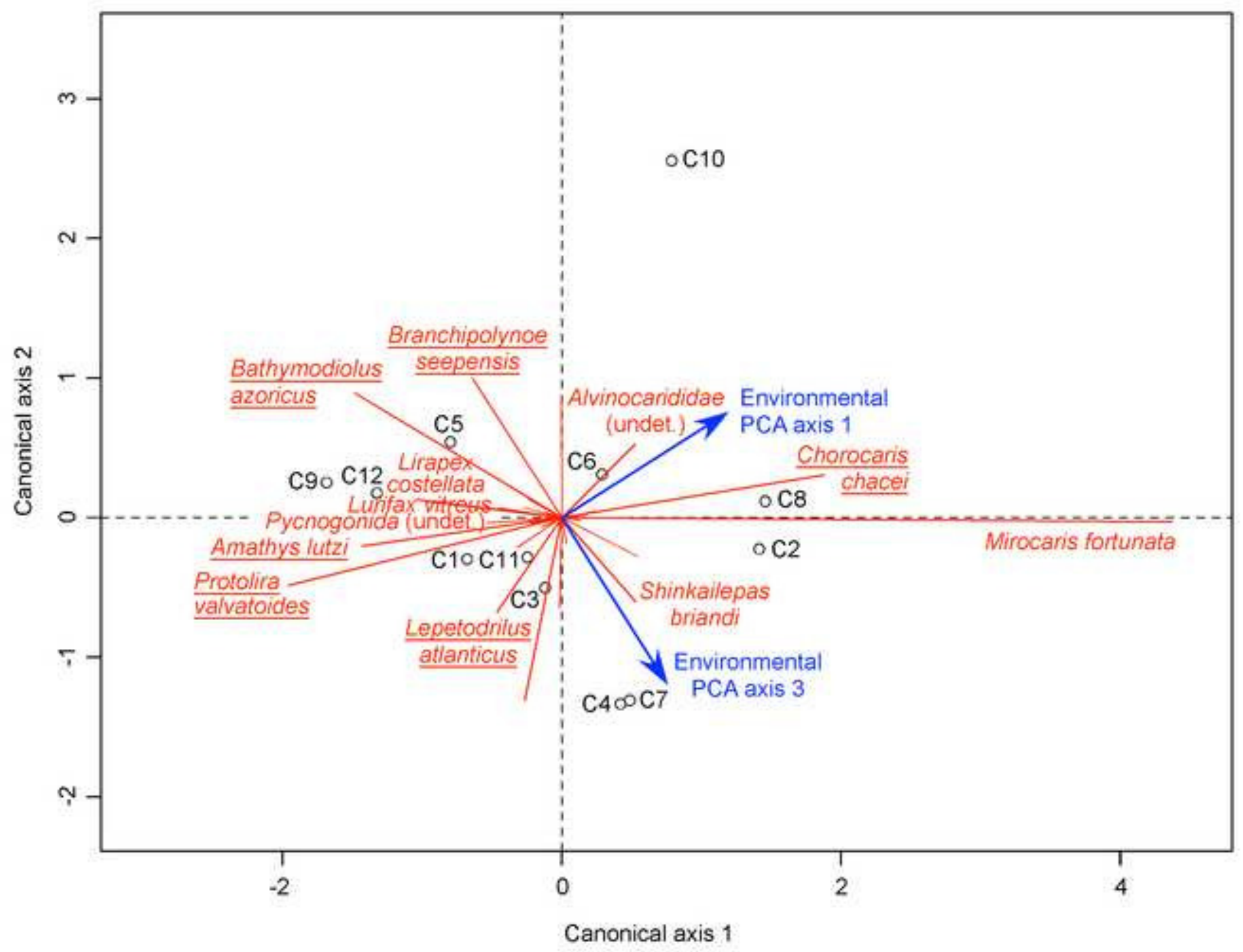




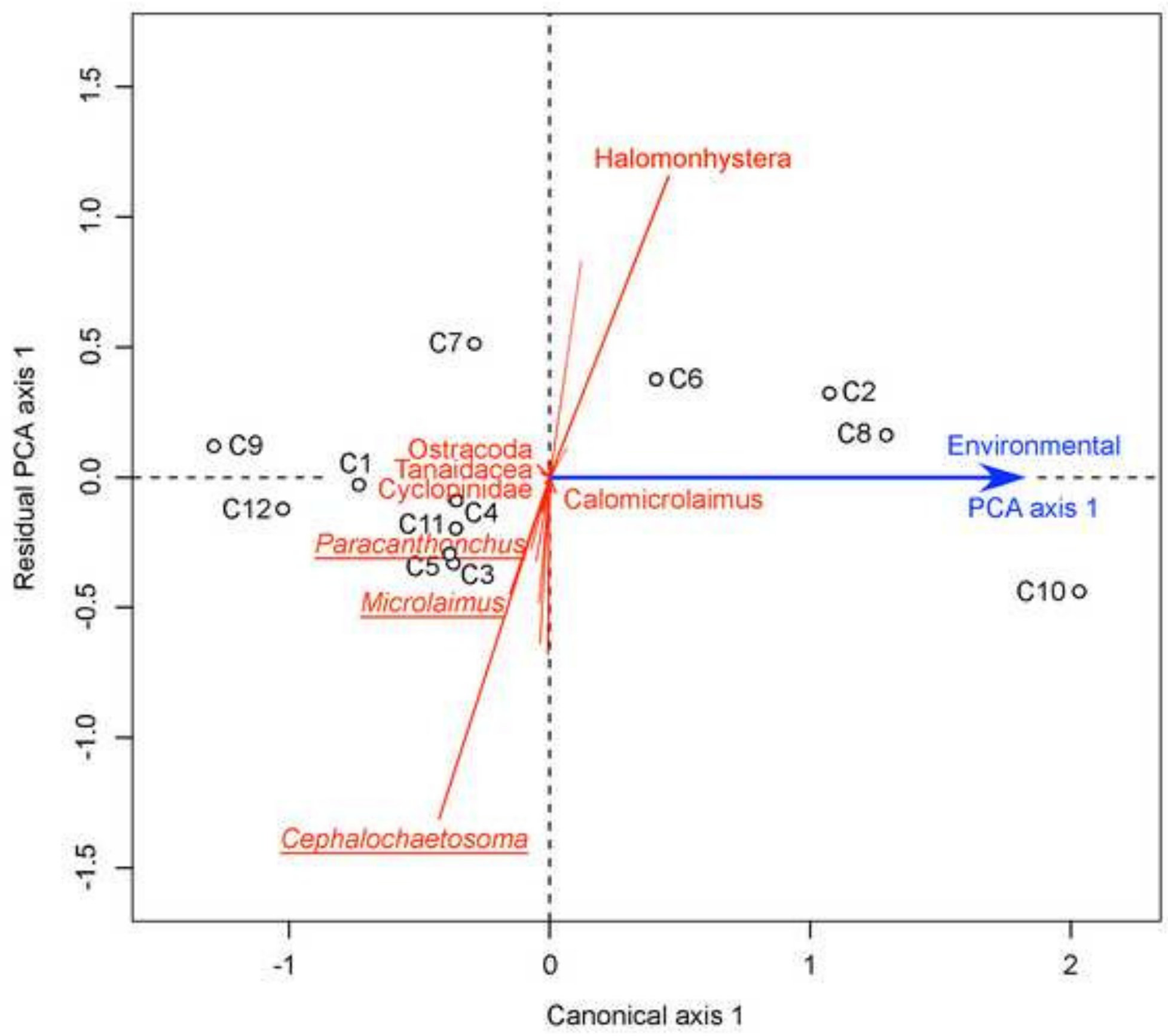




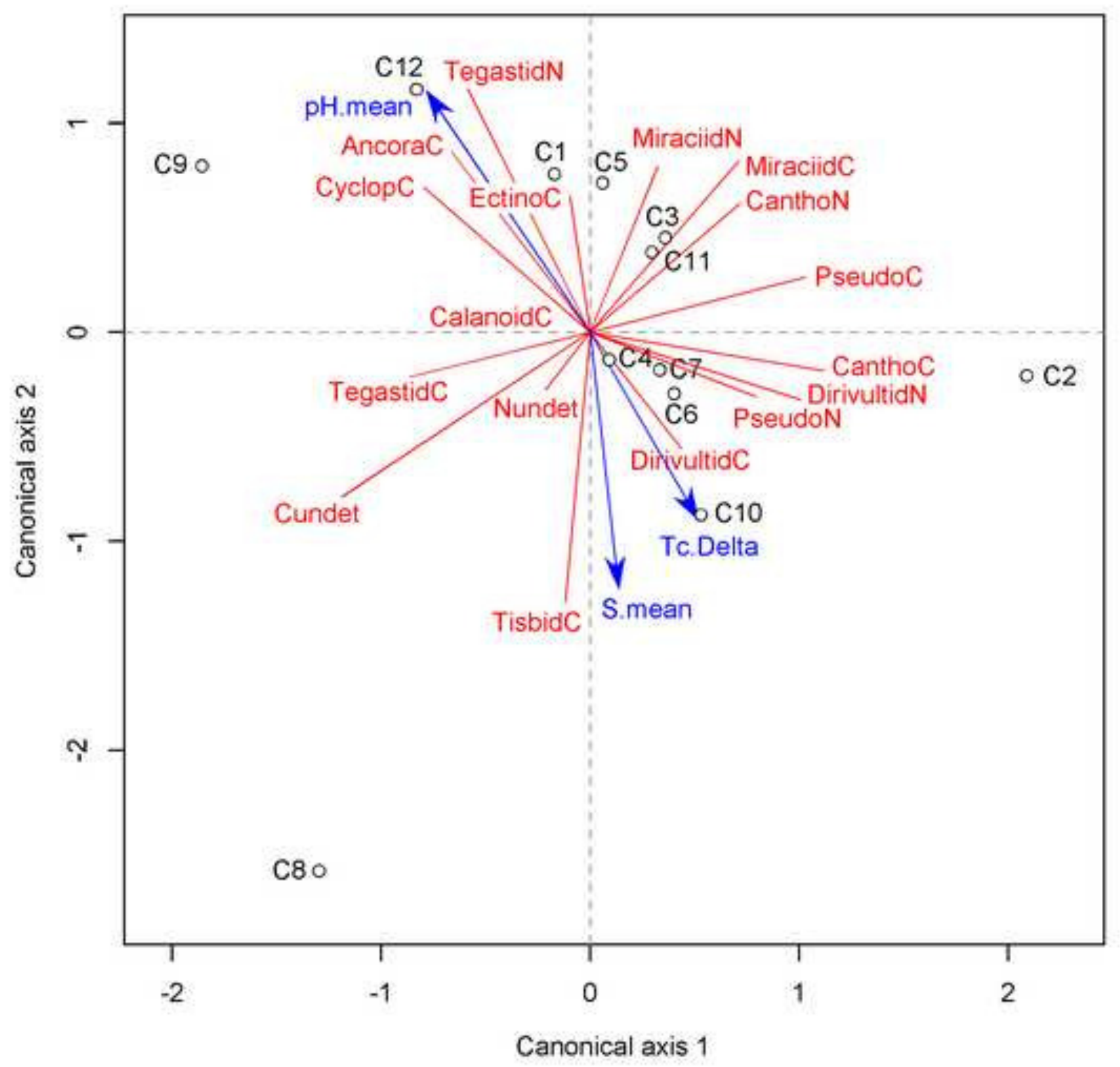


(a) LCBD, Macrofauna

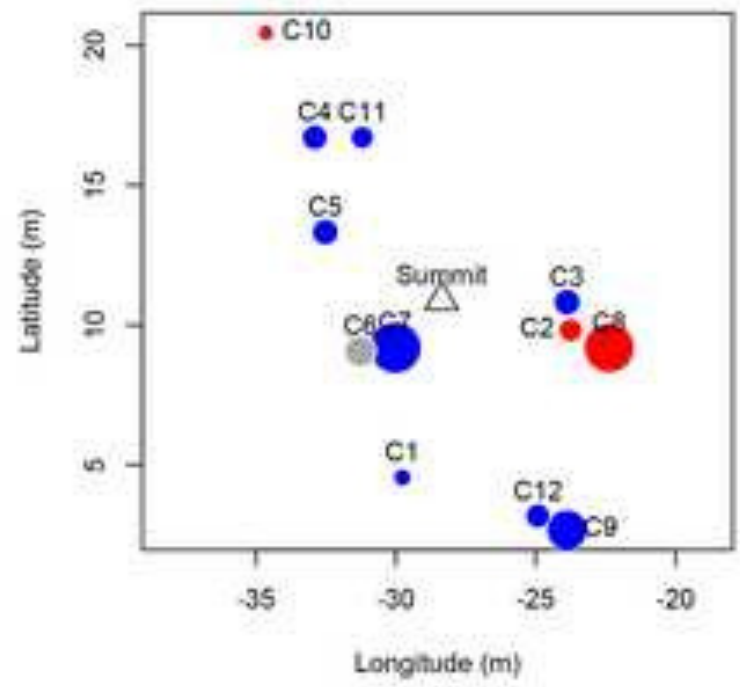

(c) Faunal density, Macrofauna

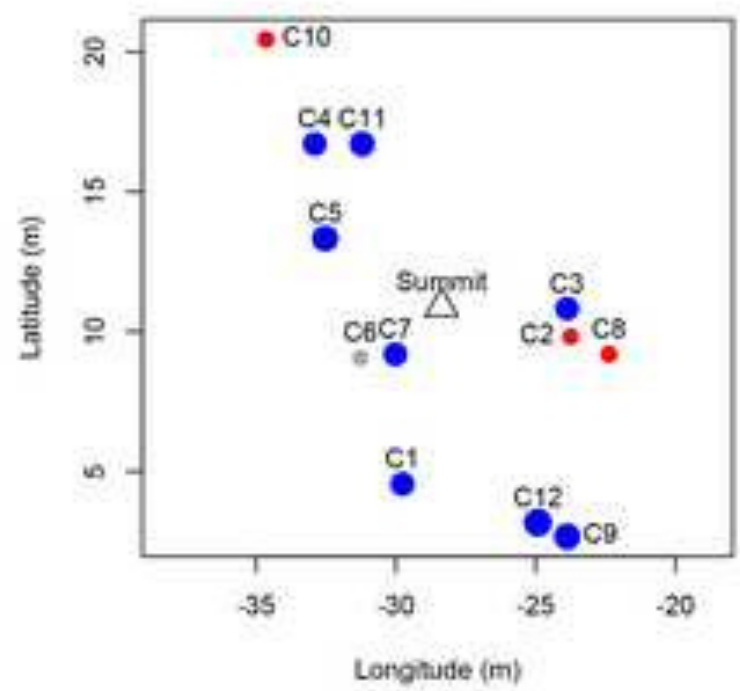

(b) Species richness, Macrofauna

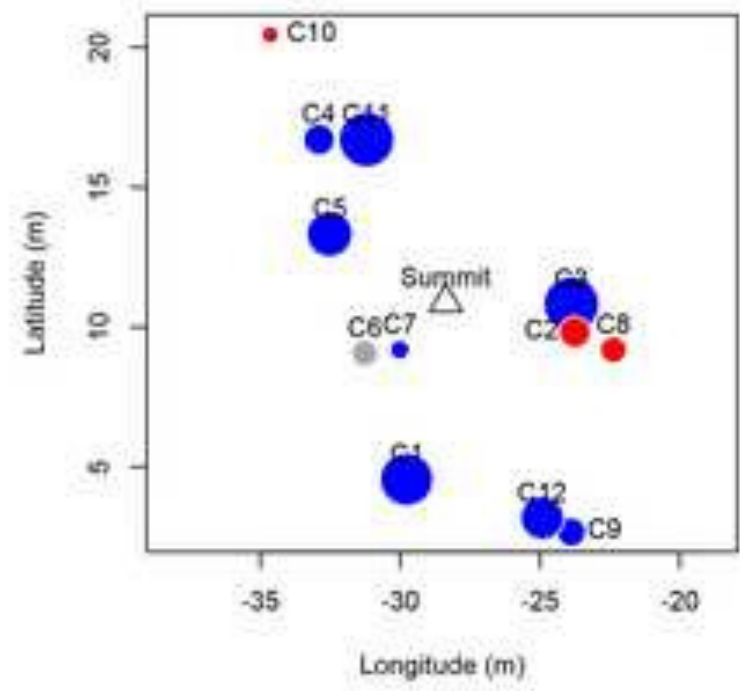

(d) $\mathrm{N}$ equivalent of Shannon, Macrofauna

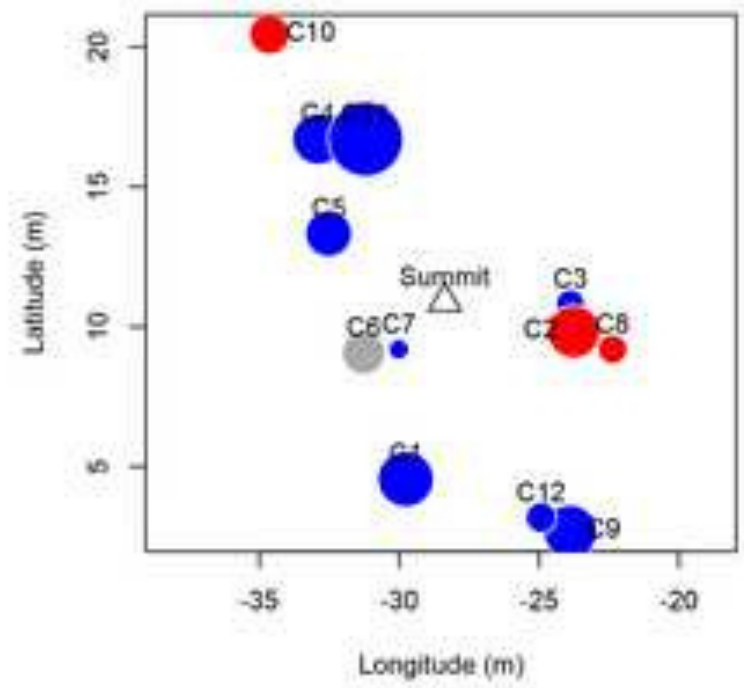


(a) LCBD, Meiofauna

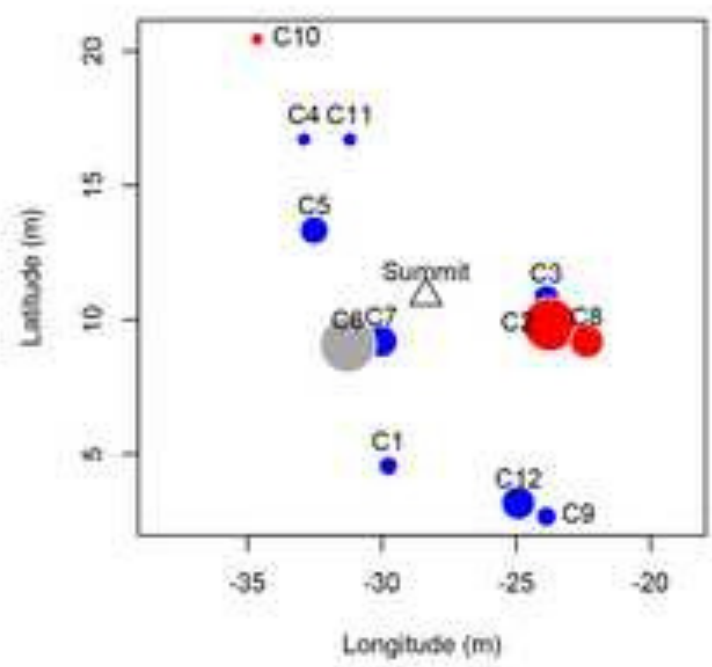

(c) Faunal density, Meiofauna

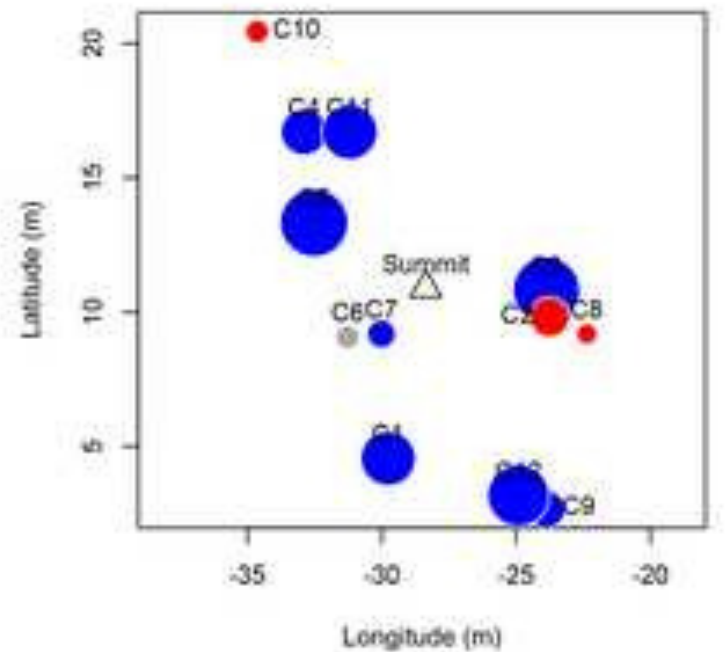

Longluibe (m) (b) Species richness, Meiofauna

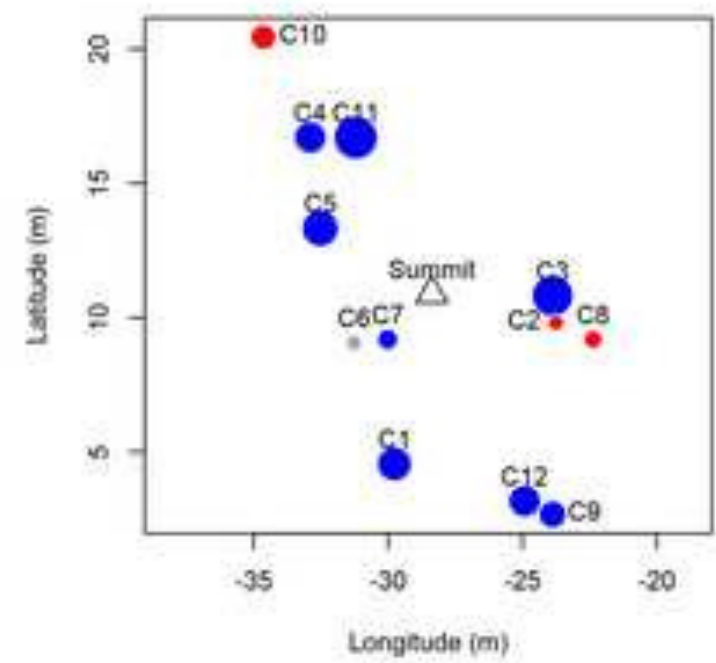

(d) N equivalent of Shannon, Meiofauna

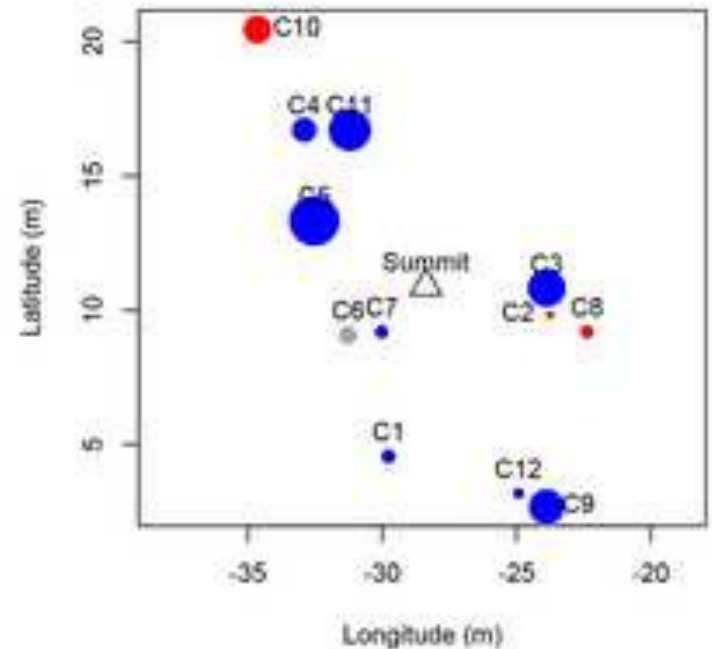




\section{Appendix A. Supporting information}
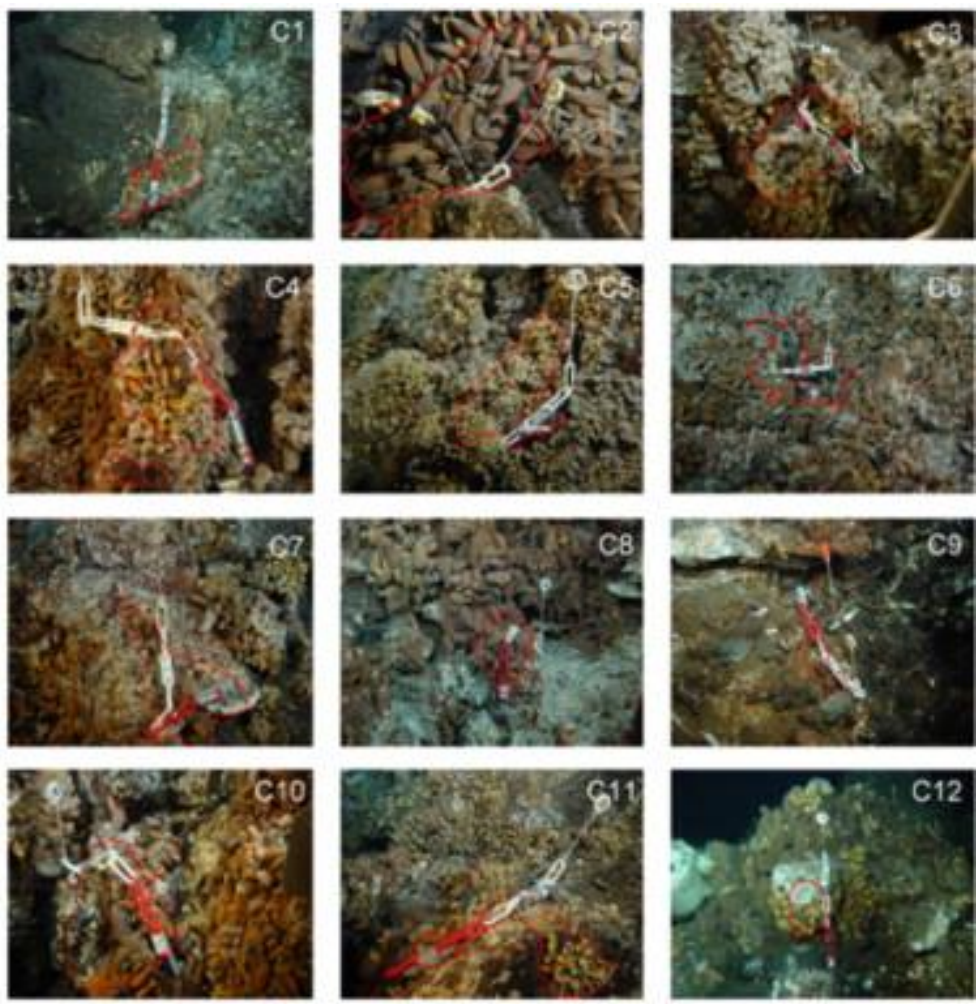

Fig S1.

Overview of the 12 sampling units and the delineation of the surface sampled, showing the assemblages and the habitats. Each chain link is $9 \mathrm{~cm}$ long. $\mathrm{C} 12$ is a bit blurry due to rising shimmering water in front of the camera lens. Figure from Cuvelier et al. 2012. 


\section{Supplementary material}

Supplementary Table 1. Densities ( $\mathrm{nb}$ of individuals $/ \mathrm{m}^{2}$ ) of the macrofaunal taxa identified in the 12 sampling units (C1-C12) on the Eiffel Tower edifice. Undet= undetermined. The total number of macrofaunal taxa for each sampling unit is also given.

\begin{tabular}{|c|c|c|c|c|c|c|c|c|c|c|c|c|}
\hline Individuals $/ \mathrm{m}^{2}$ & C1 & C2 & C3 & C4 & C5 & C6 & C7 & C8 & C9 & C10 & C11 & C12 \\
\hline Porifera & 16 & 0 & 0 & 0 & 0 & 0 & 0 & 36 & 0 & 0 & 0 & 0 \\
\hline Cnidaria-Anthozoa - Actiniaria & 0 & 0 & 12 & 0 & 0 & 0 & 0 & 0 & 3000 & 0 & 0 & 0 \\
\hline Echinodermata-Ophiuroidea-Ophiuoridae & 0 & 0 & 0 & 0 & 0 & 0 & 0 & 0 & 0 & 0 & 30 & 63 \\
\hline \multicolumn{13}{|l|}{ Polychaeta } \\
\hline Archinome sp. & 0 & 0 & 24 & 0 & 0 & 0 & 0 & 0 & 0 & 0 & 0 & 0 \\
\hline Ophryotrocha sp. & 1032 & 0 & 256 & 3531 & 388 & 0 & 0 & 0 & 0 & 0 & 1242 & 0 \\
\hline Dorvilleidae undet & 0 & 0 & 12 & 0 & 633 & 0 & 0 & 0 & 0 & 0 & 0 & 0 \\
\hline Glycera tesselata & 32 & 0 & 0 & 0 & 0 & 0 & 0 & 0 & 0 & 0 & 0 & 0 \\
\hline Glyceridae undet & 16 & 0 & 0 & 0 & 0 & 0 & 0 & 0 & 0 & 0 & 0 & 0 \\
\hline Branchinotogluma sp & 81 & 0 & 12 & 0 & 0 & 0 & 0 & 0 & 0 & 0 & 0 & 0 \\
\hline Branchinotogluma fisheri & 16 & 0 & 0 & 0 & 0 & 0 & 0 & 0 & 0 & 0 & 0 & 31 \\
\hline Branchinotogluma mesatlantica & 0 & 29 & 0 & 0 & 20 & 65 & 0 & 0 & 0 & 0 & 121 & 0 \\
\hline Branchipolynoe seepensis & 2565 & 143 & 463 & 633 & 633 & 273 & 200 & 107 & 1846 & 754 & 1394 & 2594 \\
\hline Branchipolynoe sp & 0 & 329 & 37 & 0 & 0 & 0 & 0 & 0 & 0 & 0 & 1394 & 0 \\
\hline Lepidonotopodium jouinae & 0 & 14 & 0 & 0 & 0 & 0 & 0 & 0 & 0 & 0 & 0 & 0 \\
\hline Harmothoinae & 0 & 0 & 0 & 0 & 0 & 0 & 0 & 0 & 0 & 0 & 0 & 31 \\
\hline Lepidonotinae & 0 & 0 & 37 & 0 & 0 & 0 & 0 & 0 & 0 & 0 & 30 & 0 \\
\hline Polynoidae undet & 16 & 0 & 0 & 1265 & 1551 & 156 & 300 & 0 & 0 & 0 & 91 & 0 \\
\hline Laonice asaccata & 16 & 0 & 12 & 0 & 41 & 0 & 0 & 0 & 0 & 0 & 30 & 0 \\
\hline Prionospio unilamellata & 16 & 0 & 24 & 0 & 0 & 0 & 0 & 0 & 0 & 0 & 61 & 31 \\
\hline Spionidae undet & 0 & 0 & 12 & 0 & 143 & 0 & 0 & 0 & 0 & 0 & 0 & 125 \\
\hline
\end{tabular}




\begin{tabular}{|c|c|c|c|c|c|c|c|c|c|c|c|c|}
\hline Amathys lutzi & 1984 & 529 & 9341 & 3224 & 5694 & 78 & 100 & 143 & 1385 & 393 & 1758 & 11594 \\
\hline Ampharetidae undet & 0 & 0 & 0 & 0 & 20 & 0 & 0 & 0 & 0 & 0 & 0 & 0 \\
\hline Polychaeta undet & 81 & 0 & 12 & 0 & 0 & 0 & 0 & 0 & 0 & 0 & 0 & 94 \\
\hline Hirudinea & 0 & 0 & 0 & 0 & 20 & 0 & 0 & 0 & 0 & 0 & 0 & 31 \\
\hline Bathymodiolus azoricus & 5484 & 857 & 2049 & 3776 & 7857 & 792 & 1200 & 214 & 7077 & 1475 & 4939 & 8500 \\
\hline Laeviphitus desbruyeresi & 0 & 0 & 0 & 82 & 0 & 0 & 0 & 0 & 0 & 0 & 30 & 0 \\
\hline Lepetodrilus atlanticus & 710 & 14 & 244 & 245 & 265 & 0 & 200 & 0 & 0 & 0 & 273 & 563 \\
\hline Lurifax vitreus & 16 & 0 & 0 & 0 & 20 & 0 & 0 & 0 & 385 & 0 & 0 & 0 \\
\hline Peltospira smaragdina & 0 & 0 & 0 & 0 & 0 & 13 & 0 & 36 & 0 & 0 & 0 & 0 \\
\hline Pseudorimula midatlantica & 210 & 0 & 85 & 61 & 20 & 13 & 0 & 36 & 77 & 0 & 455 & 188 \\
\hline Lirapex costellata & 81 & 0 & 0 & 0 & 122 & 0 & 0 & 0 & 1615 & 0 & 91 & 0 \\
\hline Protolira valvatoides & 1468 & 14 & 256 & 408 & 714 & 0 & 0 & 0 & 3923 & 0 & 3636 & 281 \\
\hline Shinkailepas briandi & 16 & 14 & 0 & 0 & 0 & 0 & 1100 & 36 & 0 & 0 & 0 & 0 \\
\hline Nemerta & 0 & 0 & 73 & 0 & 143 & 0 & 0 & 0 & 0 & 0 & 182 & 31 \\
\hline Amphipoda & 177 & 0 & 0 & 122 & 755 & 857 & 100 & 36 & 308 & 197 & 333 & 31 \\
\hline Isopoda & 0 & 0 & 0 & 0 & 0 & 0 & 0 & 0 & 0 & 0 & 30 & 0 \\
\hline Mirocaris fortunata & 323 & 1300 & 512 & 367 & 0 & 1325 & 10900 & 2679 & 77 & 1230 & 667 & 63 \\
\hline Chorocaris chacei & 0 & 329 & 12 & 41 & 0 & 13 & 0 & 821 & 0 & 49 & 0 & 0 \\
\hline Alvinocarididae undet & 0 & 114 & 49 & 41 & 0 & 0 & 0 & 0 & 0 & 148 & 30 & 63 \\
\hline Segonzacia mesantlantica & 0 & 71 & 12 & 0 & 0 & 39 & 0 & 107 & 154 & 0 & 152 & 0 \\
\hline Pycnogonida & 32 & 0 & 98 & 0 & 20 & 0 & 0 & 0 & 231 & 0 & 91 & 63 \\
\hline
\end{tabular}


Supplementary Table 2. Densities ( $\mathrm{nb}$ of individuals $/ \mathrm{m}^{2}$ ) of the meiofaunal taxa identified $(>250 \mu \mathrm{m})$ in the 12 sampling units (C1-C12) on the Eiffel Tower edifice. Undet= undetermined.

\begin{tabular}{|c|c|c|c|c|c|c|c|c|c|c|c|c|}
\hline Ind $/ \mathrm{m}^{2}$ & C1 & C2 & C3 & C4 & C5 & C6 & C7 & C8 & C9 & C10 & C11 & C12 \\
\hline Acari_Halacaridae & 0 & 0 & 500 & 20 & 0 & 0 & 0 & 0 & 0 & 0 & 61 & 0 \\
\hline Ostracoda & 210 & 86 & 524 & 102 & 61 & 455 & 500 & 0 & 0 & 344 & 727 & 188 \\
\hline Tanaidacea & 48 & 0 & 12 & 0 & 0 & 0 & 0 & 0 & 1077 & 0 & 61 & 31 \\
\hline Halomohystera & 24177 & 84317 & 22691 & 18883 & 32315 & 2295 & 19708 & 5755 & 8627 & 6067 & 34114 & 4842 \\
\hline Cephalochaetosoma & 262952 & 0 & 359815 & 109800 & 255285 & 470 & 1103 & 212 & 35553 & 2417 & 158166 & 455170 \\
\hline Leptolaimus & 1516 & 411 & 119938 & 0 & 142184 & 0 & 276 & 0 & 523 & 668 & 26361 & 0 \\
\hline Paracanthonchus & 9065 & 0 & 12966 & 1399 & 25852 & 0 & 0 & 85 & 2876 & 51 & 6203 & 4842 \\
\hline Desmodora & 0 & 0 & 42140 & 1399 & 71092 & 0 & 0 & 42 & 1569 & 103 & 23260 & 0 \\
\hline Microlaimus & 9065 & 0 & 22691 & 3497 & 126027 & 28 & 276 & 42 & 15163 & 308 & 55823 & 9684 \\
\hline Chromadorita & 0 & 0 & 64831 & 5595 & 25852 & 0 & 0 & 0 & 523 & 514 & 12405 & 24211 \\
\hline Epsilonema & 0 & 0 & 0 & 0 & 0 & 0 & 0 & 0 & 3137 & 0 & 0 & 0 \\
\hline Syringolaimus & 0 & 0 & 0 & 0 & 3231 & 0 & 138 & 0 & 0 & 0 & 9304 & 0 \\
\hline Viscosia & 0 & 0 & 0 & 0 & 0 & 0 & 0 & 0 & 261 & 0 & 0 & 0 \\
\hline Theristus & 0 & 0 & 0 & 0 & 0 & 0 & 0 & 0 & 1307 & 0 & 0 & 0 \\
\hline Calomicrolaimaus & 0 & 0 & 0 & 0 & 0 & 0 & 0 & 0 & 0 & 51 & 0 & 0 \\
\hline Enoplidae & 0 & 0 & 0 & 0 & 0 & 0 & 0 & 42 & 0 & 0 & 0 & 0 \\
\hline
\end{tabular}




\begin{tabular}{|c|c|c|c|c|c|c|c|c|c|c|c|c|}
\hline Nematod_undet & 32 & 0 & 5317 & 0 & 3531 & 0 & 0 & 0 & 0 & 0 & 1091 & 1531 \\
\hline Aegisthidae (Andromastax) & 0 & 0 & 0 & 0 & 0 & 0 & 0 & 0 & 0 & 0 & 30 & 0 \\
\hline Copepoda undet. & 16 & 0 & 0 & 0 & 0 & 0 & 100 & 0 & 0 & 0 & 30 & 31 \\
\hline Cyclopinidae & 145 & 0 & 2720 & 673 & 3510 & 0 & 0 & 0 & 0 & 0 & 91 & 1156 \\
\hline Dirivultidae & 6726 & 3100 & 1427 & 8367 & 367 & 7961 & 600 & 643 & 154 & 33 & 4515 & 125 \\
\hline Ectinosomatidae & 0 & 0 & 0 & 0 & 41 & 0 & 100 & 0 & 0 & 0 & 0 & 0 \\
\hline Lubbockiidae (Lubbockia) & 0 & 0 & 0 & 0 & 0 & 0 & 0 & 0 & 0 & 0 & 30 & 0 \\
\hline Miraciidae (Amphiascus) & 613 & 1071 & 3866 & 143 & 1204 & 130 & 0 & 0 & 0 & 0 & 152 & 406 \\
\hline Oithonidae (Oithona) & 0 & 0 & 12 & 0 & 0 & 0 & 0 & 0 & 0 & 0 & 0 & 0 \\
\hline Pseudotachidiidae (Xylora bathyalis) & 97 & 71 & 37 & 102 & 0 & 0 & 0 & 0 & 0 & 0 & 0 & 31 \\
\hline Spinocalanidae (new genus) & 16 & 0 & 0 & 0 & 0 & 0 & 0 & 0 & 0 & 0 & 0 & 0 \\
\hline Tegastidae (Smacigastes) & 306 & 14 & 33902 & 10633 & 56347 & 52 & 0 & 36 & 0 & 0 & 2091 & 4313 \\
\hline Tisbidae (Tisbe) & 0 & 0 & 12 & 959 & 143 & 0 & 0 & 0 & 0 & 16 & 0 & 0 \\
\hline
\end{tabular}


Supplementary Table 3. Identification of the macro- and meiofaunal taxa present in a single sampling unit and those present in 11 or all sampling units.

\begin{tabular}{|c|c|c|}
\hline & Taxa present in a single sampling unit & Taxa present in $\mathbf{1 1}$ or all sampling units \\
\hline Macrofauna & $\begin{array}{l}\text { Archinome sp } \\
\text { Glycera tesselata } \\
\text { Glyceridae undet } \\
\text { Lepidonotopodium jouinae } \\
\text { Harmothoinae } \\
\text { Ampharetidae undet } \\
\text { Isopoda }\end{array}$ & $\begin{array}{l}\text { Mirocaris fortunata } \\
\text { Branchipolynoe seepensis } \\
\text { Amathys lutzi } \\
\text { Bathymodiolus azoricus }\end{array}$ \\
\hline Meiofauna & $\begin{array}{l}\text { Epsilonema } \\
\text { Viscosia } \\
\text { Theristus } \\
\text { Calomicrolaimus } \\
\text { Enoplidae } \\
\text { Aegisthidae Andromastax(epibenthic) } \\
\text { Lubbockiidae (planctonic Lubbockia) } \\
\text { Oithonidae (planctonic Oithona) } \\
\text { Spinocalanidae (new genus close to epibenthic Methanocalanus) }\end{array}$ & $\begin{array}{l}\text { Cephalochaetosoma } \\
\text { Microlaimus } \\
\text { Halomonhystera } \\
\text { Dirivultidae }\end{array}$ \\
\hline
\end{tabular}

